\title{
Thunderstorm and stratocumulus: how does their contrasting morphology affect their interactions with aerosols?
}

\author{
S. S. Lee ${ }^{1}$, L. J. Donner ${ }^{2, *}$, and J. E. Penner ${ }^{1, *}$ \\ ${ }^{1}$ Department of Atmospheric, Oceanic, and Space Science, University of Michigan, Ann Arbor, MI, USA \\ ${ }^{2}$ Geophysical Fluid Dynamics Laboratory, Princeton University, Princeton, NJ, USA \\ *These authors contributed equally to this work.
}

Received: 28 December 2009 - Published in Atmos. Chem. Phys. Discuss.: 12 February 2010

Revised: 14 July 2010 - Accepted: 16 July 2010 - Published: 23 July 2010

\begin{abstract}
It is well-known that aerosols affect clouds and that the effect of aerosols on clouds is critical for understanding human-induced climate change. Most climate model studies have focused on the effect of aerosols on warm stratiform clouds (e.g., stratocumulus clouds) for the prediction of climate change. However, systems like the Asian and Indian Monsoon, storm tracks, and the intertropical convergence zone, play important roles in the global hydrological cycle and in the circulation of energy and are driven by thunderstorm-type convective clouds. Here, we show that the different morphologies of these two cloud types lead to different aerosol-cloud interactions. Increasing aerosols are known to suppress the conversion of droplets to rain (i.e., socalled autoconversion). This increases droplets as a source of evaporative cooling, leading to an increased intensity of downdrafts. The acceleration of the intensity of downdrafts is larger in convective clouds due to their larger cloud depths (providing longer paths for downdrafts to follow to the surface) than in stratiform clouds. More accelerated downdrafts intensify the gust front, leading to significantly increased updrafts, condensation and thus the collection of cloud liquid by precipitation, which offsets the suppressed autoconversion. This leads to an enhancement of precipitation with increased aerosols in convective clouds. However, the downdrafts are less accelerated in stratiform clouds due to their smaller cloud depths, and they are not able to induce changes in updrafts as large as those in convective clouds. Thus, the
\end{abstract}

Correspondence to: S. S. Lee

(seoungl@umich.edu) offset is not as effective, and this allows the suppression of precipitation with increased aerosols. Thus aerosols affect these cloud systems differently. The dependence of the effect of aerosols on clouds on the morphology of clouds should be taken into account for a more complete assessment of climate change.

\section{Introduction}

Aerosols act as cloud condensation nuclei (CCN) and affect cloud properties. A significant amount of effort has been put into understanding the effects of aerosols on clouds (also known as aerosol indirect effects), since these effects have been considered to be critical for the correct assessment of the change in climate induced by human activities (Penner et al., 2001).

The aerosol indirect effect was proposed based on observational and modeling studies of warm stratiform clouds (Twomey, 1977; Albrecht, 1989) and most climate studies have focused on the effects of aerosols on warm stratiform clouds for the prediction of climate change.

Recent studies, however, show that aerosols can also change the microphysical and dynamical properties of convective clouds (Khain et al., 2003, 2004, 2005, 2008; Lynn et al., 2005; Tao et al., 2007; Lee et al., 2008a, b). Aerosol effects on cloud mass and precipitation are different for convective and warm stratiform clouds (Lee et al., 2008b). These studies have shown that it is not certain whether the wellknown precipitation-suppression effect of aerosols in warm, shallow clouds applies for convective clouds. They have

Published by Copernicus Publications on behalf of the European Geosciences Union. 
suggested that precipitation from convective clouds may increase with increasing aerosols under some conditions.

Systems like the Asian and Indian Monsoon, storm tracks, and the intertropical convergence zone (ITCZ), play important roles in the global hydrologic and energy circulation, and are driven by convective clouds, often organized into mesoscale cloud ensembles (MCEs). The detrainment of ice crystals from convective clouds is the major source of ice anvils and cirrus in these systems. These cirrus clouds have significant impacts on the global radiation budget (Ramanathan et al., 1989; Liou, 2005), and their radiative properties are mainly determined by ice-crystal formation and growth in convective clouds (Houze, 1993). In addition, the precipitation from these systems plays a crucial role in the global hydrologic cycle (Houze, 1993). Hence, aerosol effects on convective clouds alter both the radiative properties of cirrus clouds and, thus, the global radiation budget, and precipitation processes and, thus, the global hydrologic cycle. Those systems located over or near continents can be significantly affected by aerosol changes. Therefore, it is important to gain an understanding of how aerosols modify radiation and precipitation in convective clouds.

It has been proposed that the delay of autoconversion (i.e., the conversion of droplets to raindrops through interactions among droplets) induced by aerosol increases could increase the mass of droplets transported to the freezing level (Rosenfeld et al., 2008). This increases the parcel-buoyancy through the increased latent-heat release from freezing, which could lead to the invigoration of convection and thus precipitation enhancement (Rosenfeld et al., 2008). However, recent studies propose that the aerosol-induced intensification of gustiness (henceforth, also referred to as the gust front in this study, cf., Houze, 1993) at the initial stage of cloud development could also lead to increased updrafts and thus increased condensation and precipitation in the subsequent development of convective clouds with increased aerosols (Khain et al., 2003, 2005; Lynn et al., 2005; Tao et al., 2007; Lee et al., 2008a, b). It has been shown that the aerosol-induced invigoration of convection and precipitation enhancement can be simulated in the absence of freezing through the intensification of gustiness in deep convective clouds reaching the tropopause (Lee et al., 2008a, b).

The aerosol-induced intensification of gustiness depends on the convective available potential energy (CAPE) level controlling the vigor of the convection and thus the topheight of convective clouds (Lee et al., 2008b). The aerosolinduced intensification of gustiness is larger at higher CAPE which supports the development of deeper clouds with higher cloud-top heights (Lee et al., 2008b). This implies that the relative importance of the effects of aerosols on freezing as proposed by Rosenfeld et al. (2008) compared to those on gustiness may vary with varying CAPE. We propose that the effects of aerosols on gustiness are more critical than those on freezing to the determination of the aerosol-induced changes in precipitation and associated microphysics, and thus, cloud mass (which plays an important role in the determination of cloud radiative properties) in deeper clouds.

This study examines the role of aerosol effects on gustiness in explaining the aerosol-induced changes in precipitation, microphysics, and cloud mass in deep convective clouds. The study also aims to gain an understanding of how the relative roles of aerosol effects on gustiness to those on freezing varies with the CAPE level by comparing a case of deep convective clouds forming with high CAPE to a case of comparatively shallow convective clouds forming with low CAPE. Finally, the response of convective clouds to aerosols is compared to those of stratiform clouds. This gives us an insight into how the effects of aerosols on convective clouds are different from those on warm stratiform clouds which have garnered much more attention than convective clouds for the understanding of the effects of aerosols on climate.

\section{Theoretical background: gust front}

Figure 1 schematically describes a supercell thunderstorm (also referred to as a deep convective cloud here) at its mature stage. Figure 1 shows the gust front formed by cold downdrafts reaching the low-level atmosphere and the surface and then spreading out to face the warm ambient air. The ambient air is pushed upward by the gust front to form subsequent new cells. It is well-known that the intensity and the number of the subsequent thunderstorm cells are closely linked to the intensity of this gust front (Houze, 1993). The downdrafts are driven by the evaporative cooling of droplets and rain and thus their intensities are generally proportional to the evaporative cooling.

It has been shown that the aerosol-induced delay of autoconversion increases droplets available for evaporative cooling, leading to more and stronger downdrafts and thus gust fronts (Khain et al., 2003, 2005; Lynn et al., 2005; Tao et al., 2007; Lee et al., 2008a, b). This leads to the subsequent more and stronger convection (and thus updrafts and condensation), and more precipitation.

\section{Cloud-system resolving model (CSRM)}

The Goddard Cumulus Ensemble (GCE) model (Tao et al., 2003), which is a three-dimensional nonhydrostatic compressible model, is used as a CSRM here. The detailed equations of the dynamical core of the GCE model are described by Tao and Simpson (1993) and Simpson and Tao (1993).

The subgrid-scale turbulence used in the GCE model is based on work by Klemp and Wilhelmson (1978) and Soong and Ogura (1980). In their approach, one prognostic equation is solved for the subgrid-scale kinetic energy, which is then used to specify the eddy coefficients. The effect of condensation on the generation of subgrid-scale kinetic energy is also incorporated into the model. 


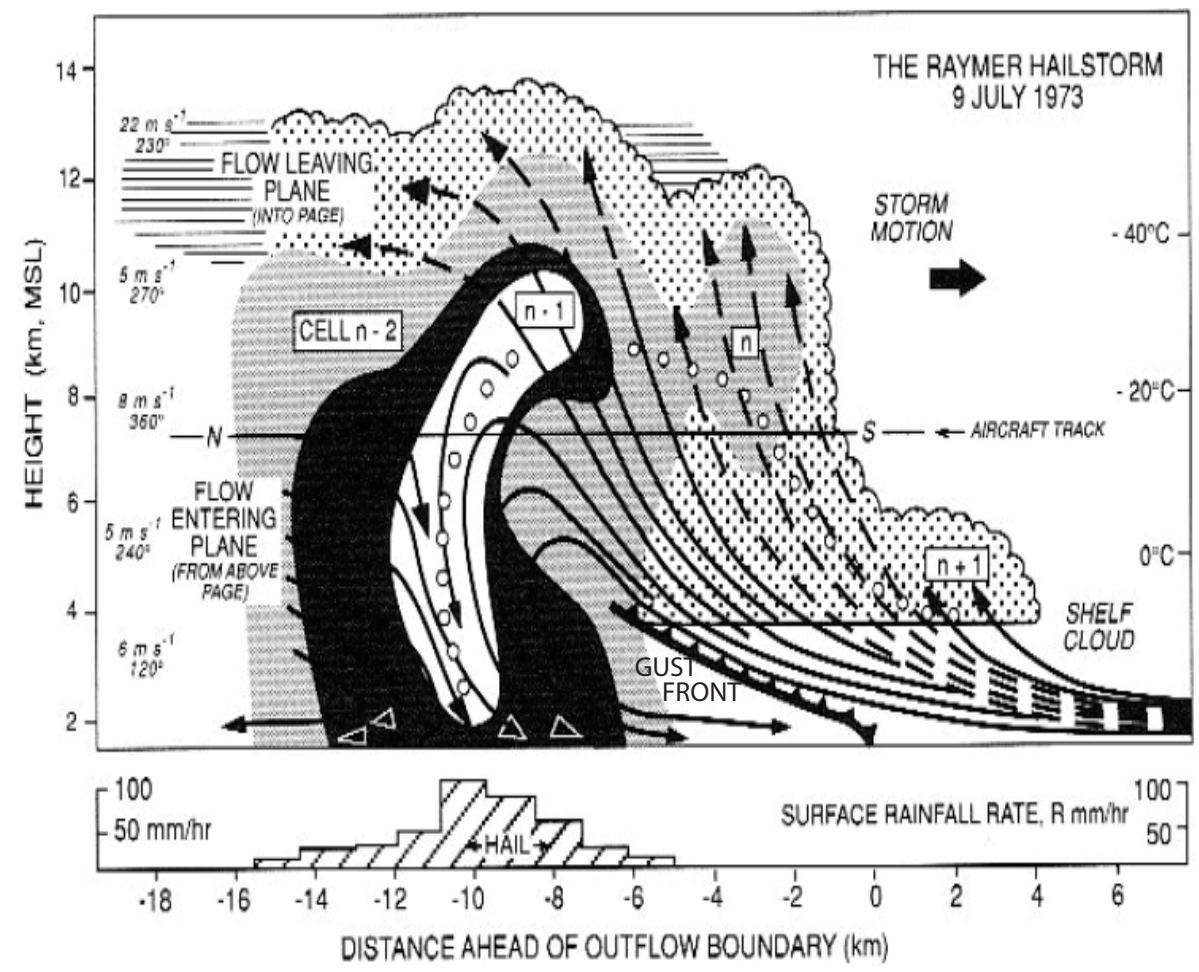

Fig. 1. Schematic model of a deep convective supercell thunderstorm observed near Raymer, Colorado. The solid lines are streamlines of flow relative to the moving system; they are broken on the left side of the figure to represent flow into and out of the plane and on the right side of the figure to represent flow remaining within a plane a few kilometers closer to the reader. The chain of open circles represents the trajectory of a hailstone. Lightly stippled shading represents the extent of cloud and the two darker grades of stippled shading represent radar reflectivities of 35 and $45 \mathrm{dBZ}$. The white area enclosing the hail trajectory is bounded by $50 \mathrm{dBZ}$. The gust front is represented by a solid line with triangles. Adapted from Houze (1993).

To represent microphysical processes, bin microphysics can be a good candidate. However, there are still unresolved issues related to application of bin schemes to CSRMs with relatively low spatial resolutions (on the order of $100 \mathrm{~m}-$ $1000 \mathrm{~m}$ ) used for mesoscale studies (including this study) (e.g., droplet nucleation, cf., Saleeby and Cotton, 2004, and the impact of entrainment and mixing on cloud droplet spectra, cf., Grabowski, 2006). Also, in general, high computational cost required by bin microphysics elongates simulation wall-clock time by a factor of $30-40$ and this disables us from completing simulations here within a practical time frame. Hence, the GCE model adopts the double-moment bulk representation of Saleeby and Cotton (2004) based on Morrison et al. (2009) and Seifert et al. (2006) for simulations here. Morrison et al. (2009) showed the double-moment microphysics was able to simulate convective clouds with a fairly good agreement with observations. Seifert et al. (2006) indicated that double-moment schemes were the most promising microphysical compromise between computational cost and realistic simulations to be used in models for mesoscale cloud-resolving simulations. Also, we want to note that the double-moment microphysics here considers aerosol properties for homogeneous and heterogeneous nucleation of ice particles explicitly, which is not featured in most of bin microphysics; this will be described in more detail in the following sections.

The size distribution of hydrometeors obeys a generalized gamma distribution:

$n(D)=\frac{N_{t}}{\Gamma(v)}\left(\frac{D}{D_{n}}\right)^{\nu-1} \frac{1}{D_{n}} \exp \left(-\frac{D}{D_{n}}\right)$

where $D$ is the equivalent spherical diameter $(\mathrm{m}), n(D) d D$ the number concentration $\left(\mathrm{m}^{-3}\right)$ of particles in the size range $d D$, and $N_{t}$ the total number of particles $\left(\mathrm{m}^{-3}\right)$. Also, $v$ is the gamma distribution shape parameter (non-dimensional) and $D_{n}$ is the characteristic diameter of the distribution (m). It is well known that hydrometeors follow the gamma distribution and, thus, bulk scheme with the gamma distribution has been used in numerous case studies and showed good agreement with observation (e.g., Lee et al., 2008a, 2009a, b; Walko et al., 1995; Meyers et al, 1997; Saleeby and Cotton, 2004). Also, Seifert et al. (2006) indicated that the exact shape of size distribution of hydrometeors was not of importance to the reasonable simulation of precipitation. This supports the use of approximated form of size distribution (i.e., gamma distribution in this study). 
Full stochastic collection solutions for self-collection among cloud droplets and for rain drop collection of cloud droplets based on Feingold et al. (1988) are obtained using realistic collection kernels from Long (1974) and Hall (1980). Hence, this study does not constrain the system to a threshold mixing ratio and constant or average collection efficiencies. The full stochastic collection solutions used in this study lowers the uncertainty from the use of a threshold mixing ratio and constant or average collection efficiencies significantly as shown in Seifert et al. (2006). Following Walko et al. (1995), lookup tables are generated and used in each collection process. This enables fast and accurate solutions to the collection equations.

The philosophy of bin representation is adopted for calculations of the hydrometeor sedimentation and collection. The bin sedimentation is simulated by dividing the gamma distribution into discrete bins and then building lookup tables to calculate how much mass and number in a given grid cell falls into each cell beneath a given level in a given time step. Thus, this study does not rely on a mass-weighted fall speed for sedimentation. 36 bins are used for the collection and the sedimentation. This is because Feingold et al. (1999) reported that the closest agreement between a full bin-resolving microphysics model in a large eddy simulation (LES) of marine stratocumulus cloud and a bulk microphysics representation was obtained when the collection and the sedimentation were simulated by emulating a full-bin model with 36 bins.

Cloud droplets are divided into small and large cloud droplets. Small and large cloud droplets range $2-40 \mu \mathrm{m}$ and $40-80 \mu \mathrm{m}$ in diameter, respectively. The $40-\mu \mathrm{m}$ division between the two droplet modes is natural because it is well known that collection rates for droplets smaller than this size are very small, whereas droplets greater than this size participate in vigorous collision and coalescence. The large-clouddroplet mode is allowed to interact with all other species (i.e., the small-cloud-droplet mode, rain, pristine ice, snow, aggregates, hail, and graupel). The large-cloud-droplet mode plays a significant role in the collision-coalescence process by requiring droplets to grow at a slower rate as they pass from the small-cloud-droplet mode to rain, rather than being transferred directly from the small-cloud-droplet mode to rain.

All the cloud species here have their own terminal velocity. The terminal velocity of each species is expressed in power law relations (See Eq. (7) in Walko et al., 1995) based on the fall-speed formulations in Rogers and Yau (1989). A Lagrangian scheme is used to transport the mixing ratio and number concentration of each species from any given grid cell to a lower height in the vertical column, following Walko et al. (1995).

The rate of vapor diffusion on hydrometeors is explicitly represented based on the predicted supersaturation (see Sect. 2 and Lee et al., 2009b for more details). This is different from a saturation adjustment where vapor diffusion is diagnosed based on environmental conditions such as temperature and water vapor. Lee et al. (2009b) and Lee and Pen- ner (2010) showed that the supersaturation prediction prevented an overestimation of condensation and evaporation as compared to a saturation adjustment. This prevention improves simulations of interactions between microphysics and dynamics, which are associated with latent-heat distributions.

The cloud-droplet nucleation parameterization of AbdulRazzak and Ghan (2000, 2002), which is based on Köhler theory, is used. This parameterization combines the treatment of multiple aerosol types and a sectional representation of size to deal with arbitrary aerosol mixing states and arbitrary aerosol size distributions. The bulk hygroscopicity parameter for each category of aerosol is the volume-weighted average of the parameters for each component taken from Ghan et al. (2001). In applying the Abdul-Razzak and Ghan parameterization, the size spectrum for each aerosol category is divided into 30 bins.

Lohmann and Diehl's (2006) parameterizations, taking into account the dependence of ice nuclei (IN) activation on dust and black carbon (BC) aerosol mass concentration, are used for contact, immersion, and condensation-freezing activation of IN. For contact activation:

$$
\frac{d N_{\mathrm{CNT}}}{d t}\left(\mathrm{~m}^{-3} \mathrm{~s}^{-1}\right)=m_{\mathrm{io}} D_{\mathrm{ap}} 4 \pi r_{\mathrm{cm}} N_{a, \mathrm{cnt}} \frac{\rho_{a} n_{c}^{2}}{q_{c}}
$$

where $\frac{d N_{\mathrm{CNT}}}{d t}$ is the rate of the production of ice-crystal number concentration via contact freezing, $m_{\mathrm{io}}\left(10^{-12} \mathrm{~kg}\right)$ is the original mass of a newly formed ice crystal, $D_{\mathrm{ap}}\left(\mathrm{m}^{2} \mathrm{~s}^{-1}\right)$ is the Brownian aerosol diffusivity, $r_{\mathrm{cm}}$ is volume-mean droplet radius, $N_{a, \text { cnt }}\left(\mathrm{m}^{-3}\right)$ is the number concentration of contact nuclei and $n_{c}$ is the number mixing ratio of droplets. $D_{\text {ap }}$ is given by

$D_{\text {ap }}=\frac{k T C_{c}}{6 \pi \eta r_{m}}$

where $k$ is the Boltzmann constant, $T$ is the temperature, $\eta$ is the viscosity of air $\left\{\eta=10^{-5}\left(1.718+0.0049\left(T-T_{0}\right)-\right.\right.$ $\left.1.2 \times 10^{-5}\left(T-T_{0}\right)^{2}\right)$ in $\left.\mathrm{kg} \mathrm{m}^{-1} \mathrm{~s}^{-1}\right\}, r_{m}$ is the aerosol mode radius, and $C_{c}$ is the Cunningham correction factor $\left[C_{c}=\right.$ $\left.1+1.26\left(\frac{\lambda}{r_{m}}\right)\left(\frac{p_{0}}{p}\right)\left(\frac{T}{T_{0}}\right)\right]$. The aerosol mode radius is taken to be $0.2 \mu \mathrm{m}$ for dust and $0.1 \mu \mathrm{m}$ for BC. $\lambda$ is the mean free path length of air ( $\lambda=0.066 \mu \mathrm{m}$ at the surface), $p_{0}$ and $T_{0}$ refer to the standard pressure of $101325 \mathrm{~Pa}$ and freezing temperature of $273.16 \mathrm{~K} . N_{a \text {,cnt }}$ is obtained from the number concentration of aerosol particles consisting of $\mathrm{BC}$ and dust, multiplied by a temperature dependence for the individual species. This temperature dependence is based on Fig. 1 in Lohmann and Diehl (2006). Here, for dust, the temperature dependence of montmorillonite is adopted (Lohmann and Diehl, 2006). For immersion and condensation-freezing activation: 


$$
\frac{d N_{\mathrm{IMM}}}{d t}\left(\mathrm{~m}^{-3} \mathrm{~s}^{-1}\right)=N_{a, \mathrm{imm}} \exp \left(T_{0}-T\right) \frac{d T}{d t} \frac{\rho_{a} q_{c}}{\rho_{w}}
$$

where $\frac{d N_{\mathrm{IMM}}}{d t}$ is the rate of the production of ice-crystal number concentration via immersion and condensation freezing, $T_{0}$ freezing temperature. $N_{a, \text { imm }}\left(\mathrm{m}^{-3}\right)$ is the number concentration of immersion and condensation nuclei calculated as the number concentration of $\mathrm{BC}$ and dust aerosols, multiplied by the temperature dependence for immersion and condensation freezing from Fig. 1 in Lohmann and Diehl (2006). As for contact freezing, the temperature dependence of montmorillonite is adopted for dust. For deposition nucleation, the parameterization of Möhler et al. (2006), calculating the fraction of dust activated, is implemented:

$\frac{d N_{\mathrm{DEP}}}{d t}\left(\mathrm{~m}^{-3} \mathrm{~s}^{-1}\right)=N_{a, \operatorname{dep}}\left(\exp \left[a\left(S_{i}-S_{0}\right)\right]-1\right)$

where $\frac{d N_{\mathrm{DEP}}}{d t}$ is the rate of the production of ice-crystal number concentration via depositional freezing, $a$ and $S_{0}$ are non-dimensional empirical constants determined from chamber experiments, which are dependent on aerosol properties. Here $a$ and $S_{0}$ are set to 4.77 and 1.07, respectively, based on experiments for desert dust. $N_{a \text {,dep }}$ is the number concentration of deposition nuclei $\left(\mathrm{m}^{-3}\right)$ calculated from the predicted total dust mass concentration. Equation (4) is applied at temperatures colder than $-40{ }^{\circ} \mathrm{C}$ and restricted to $S_{0}<S_{i}<1.63+6.52 \times 10^{-3} \times\left(T-T_{0}\right)$, corresponding to the measured saturation region of Field et al. (2006) where pure deposition nucleation occurs. The parameterization is limited to activating a maximum of $5 \%$ of the dust, following the measurements of Field et al. (2006). As indicated by the experiments of Field et al. (2006), Eq. (4) is only valid at temperatures below $-40^{\circ} \mathrm{C}$. At temperatures warmer than $-40^{\circ} \mathrm{C}$, the parameterizations of Meyer et al. (1992) and DeMott et al. (2003), multiplied by a scaling factor to consider the dependence of IN activation on dust mass concentration, are used. Those parameterizations are applied to grid points with no cloud liquid to ensure only deposition nucleation is calculated. It is limited to activating a maximum of $0.5 \%$ of the dust, since Field et al. (2006) found deposition nucleation did not activate more than $0.5 \%$ of the dust at temperatures warmer than $-40^{\circ} \mathrm{C}$. Details of those parameterizations can be found in Appendix A.

Secondary production of ice occurs by the Hallet-Mossop process of rime splintering (Hallet and Mossop, 1974) and involves 350 ice splinters emitted for every milligram of rimed liquid at $-5.5^{\circ} \mathrm{C}$. The number of splinters per milligram of rime liquid is linearly interpolated to zero between -3 and $-8^{\circ} \mathrm{C}$.

Homogeneous aerosol (haze particles) freezing is assumed to occur instantaneously when a size- and temperaturedependent critical supersaturation with respect to ice for the freezing is exceeded. It is represented by considering the predicted size distribution of unactivated aerosols. A lookup table for the critical supersaturation ratio at which $\mathrm{CCN}$ freeze homogeneously is based on the theory proposed by Koop et al. (2000).

Homogenous droplet freezing is performed by instantaneous conversion of supercooled cloud droplets to cloud ice at temperatures colder than $-36{ }^{\circ} \mathrm{C}$. Virtually almost all homogeneous freezing of cloud liquid occurs in a narrow layer between about $-35^{\circ} \mathrm{C}$ and $-37^{\circ} \mathrm{C}$ that is about $200 \mathrm{~m}$ deep (Heymsfield et al., 2005). The larger droplets in the droplet size distribution freeze first and their vapor growth can cause total evaporation of the smaller supercooled droplets. Heymsfield et al. (2005) found that the fraction of small droplets disappearing as a result of evaporation is higher at lower vertical velocities. Typical vertical resolutions of CSRMs cannot resolve the decline of supersaturation with increasing altitude within this layer, which is caused by the vapor growth of newly frozen droplets. They cannot resolve the precise temperature at which exact water saturation is reached, which determines the fraction of droplets to be evaporated. Hence, a parameterization of the evaporation of small droplets during homogeneous freezing is needed, irrespective of the time-step. In the present study, the fraction by number of cloud droplets that are frozen homogeneously just above the $-36^{\circ} \mathrm{C}$ level is parameterized with a 3-D look-up table as a function of the vertical velocity, the predicted supersaturation at the level just below the homogeneous freezing, and the product of $n_{c}$ and $\left\langle D_{c}>\right.$. Here, $n_{c}$ and $D_{c}$ are the number mixing ratio and diameter of droplets, respectively, and " $<>$ " denotes a number weighted average over the particle size distribution. Data for the freezing fraction are obtained from a spectral microphysics parcel model, which is a simplified version of the model of Phillips et al. (2005). This procedure is identical to that elucidated by Phillips et al. (2007).

The parameterizations developed by Chou and Suarez (1999) for shortwave radiation and by Chou et al. (1999), and Kratz et al. (1998) for longwave radiation have been implemented in the GCE model. The solar radiation scheme includes absorption due to water vapor, $\mathrm{CO}_{2}, \mathrm{O}_{3}$, and $\mathrm{O}_{2}$. Interactions among the gaseous absorption and scattering by clouds, molecules, and the surface are fully taken into account. Reflection and transmission of a cloud layer are computed using the $\delta$-Eddington approximation. Fluxes for a composite of layers are then computed using the twostream adding approximation. In computing thermal infrared fluxes, the k-distribution method with temperature and pressure scaling is used to compute the transmission function.

To account for the variability of crystal type under different environmental conditions, the capacitance and massdimensional relations of pristine ice crystals and snow are allowed to vary. Since the model does not keep track of the history of all crystals, a simple diagnostic check of the ambient temperature and saturation conditions at each grid location is performed during each time-step to determine the crystal habit; see Table 1 in Meyers et al. (1997) for the habit diagnosis adopted here. The habit diagnosis impacts the model in 


\section{Aerosol Mass Profiles}

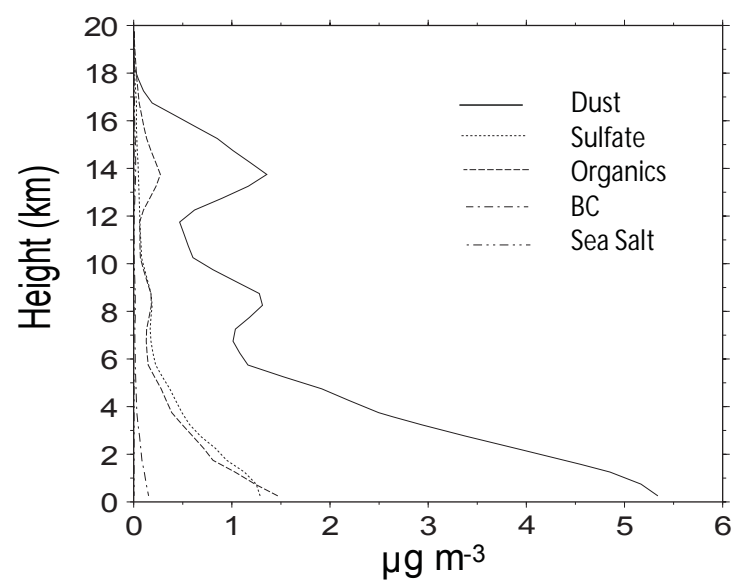

Fig. 2. Vertical profiles of aerosol species. Salt is present, but its values are less than $0.01 \mu \mathrm{g} \mathrm{m}^{-3}$.

several ways. The capacitance is dependent on crystal type (Harrington et al., 1995) and may change the growth characteristics of the crystals. Different types of crystals fall at different speeds which is determined by the power law relation

$v_{t}=a_{\mathrm{vt}} D^{b_{\mathrm{vt}}}$

where $D$ is the crystal maximum dimension and $a_{\mathrm{vt}}$ and $b_{\mathrm{vt}}$ are constants for a given crystal habit (see Walko et al., 1995 for details of these constants).

\section{Integration design}

\subsection{Deep convective clouds}

Aerosol effects on deep convective clouds are examined by performing a one-day three-dimensional simulation of an observed MCE with a time step of 10 seconds. The MCE was observed during the Atmospheric Radiation Measurement (ARM) sub-case A (13:30 UTC 29 June-13:30 UTC 30 June 1997$)$ campaign at $\left(36.61^{\circ} \mathrm{N}, 97.49^{\circ} \mathrm{W}\right)$. This case is referred to as DEEP, henceforth.

It is assumed that there are five chemical components of aerosols: dust, sulfate, organics, $\mathrm{BC}$, and sea salt. Aerosols bearing sulfate or organics are assumed to act only as $\mathrm{CCN}$ and to be internally mixed. Aerosols composed of either dust or BC are assumed to act only as IN and to be externally mixed. The aerosol mass mixing ratio is advected and diffused within clouds and is reset to the background value outside of clouds. The background aerosols are assumed to not vary spatiotemporally. However, results here hold when the background aerosols vary spatiotemporally due to the cloud processing of aerosols. Initially the aerosol
Aerosol Size Distribution

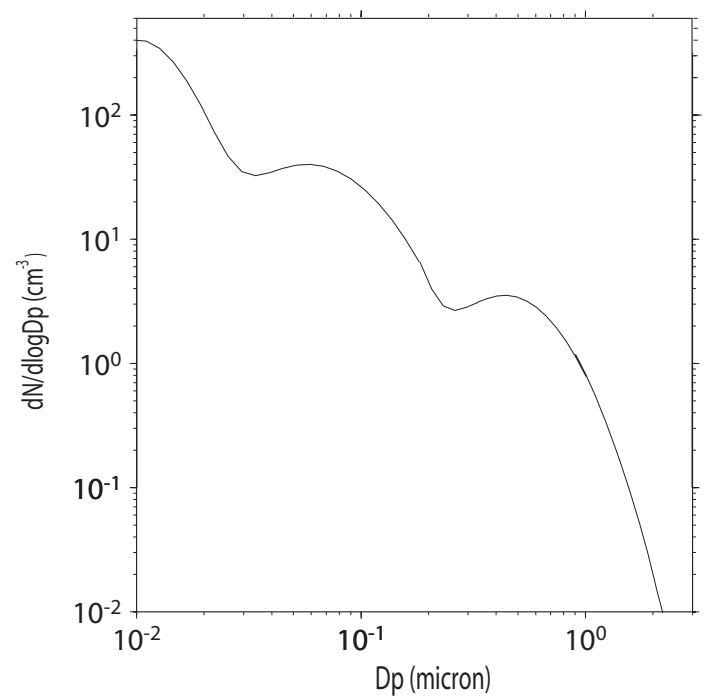

Fig. 3. Size distribution of aerosols acting at the surface. $N$ and $D_{p}$ denote the number concentration and diameter of dry aerosols, respectively.

mass mixing ratio is everywhere set equal to the background value. The aerosol number concentration in each bin of the size spectrum is determined based on the predicted aerosol mass, aerosol particle density, and an assumed log-normal size distribution. Aerosols depleted by the activation (nucleation scavenging) both at and above the cloud base are subtracted from the aerosol mass within clouds.

The background aerosol profiles for these simulations are extracted from a version of the GFDL AM2 (2004) nudged by NCEP re-analysis with aerosol chemistry. The details of procedure for nudging NCEP reanalysis are similar to Timmreck and Schulz (2004). Aerosol chemistry is adopted from Chin et al. (2002) and Koch et al. (1998). Chemical reactions include DMS oxidation by $\mathrm{OH}$ during the day and by $\mathrm{NO}_{3}$ during the night to form $\mathrm{SO}_{2}$, and $\mathrm{SO}_{2}$ oxidation by $\mathrm{OH}$ in the gas phase and by $\mathrm{H}_{2} \mathrm{O}_{2}$ in the aqueous phase to form sulfate. The predicted mass profiles, averaged over a oneday period, are obtained at $\left(36.61^{\circ} \mathrm{N}, 97.49^{\circ} \mathrm{W}\right)$ on 29 June 1997. The vertical profiles of background aerosols shown in Fig. 2 are applied for the simulation, referred to as the highaerosol run in DEEP. Figure 3 shows the background aerosol size distribution adopted for aerosol diameters between 0.01 and $1 \mu \mathrm{m}$ at the surface.

The horizontal domain length is set to $168 \mathrm{~km}$ in both the east-west and north-south directions to capture the mesoscale structure of the storm while the vertical domain length is set to $20 \mathrm{~km}$ to cover the troposphere and the lower stratosphere. The horizontal grid length is $200 \mathrm{~m}$ while the vertical grid length $100 \mathrm{~m}$. 
Table 1. Summary of simulations.

\begin{tabular}{|c|c|c|c|c|c|c|c|c|}
\hline Case & Simulation & Location & Period & $\begin{array}{l}\text { Surface aerosol } \\
\text { number } \\
\left(\mathrm{cm}^{-3}\right)\end{array}$ & Meteorology & $\begin{array}{l}\text { Domain size } \\
\left(\mathrm{km}^{3}\right)\end{array}$ & Ice physics & $\begin{array}{l}\text { Grid spacing } \\
(\mathrm{m})\end{array}$ \\
\hline \multirow{4}{*}{ DEEP } & $\begin{array}{l}\text { High-aerosol } \\
\text { run }\end{array}$ & $\begin{array}{l}\left(36.61^{\circ} \mathrm{N}\right. \\
\left.97.49^{\circ} \mathrm{W}\right)\end{array}$ & $\begin{array}{l}\text { 13:30 UTC } \\
29 \text { June-13:30 } \\
\text { UTC } 30 \text { June } \\
1997\end{array}$ & $\sim 4000$ & $\begin{array}{l}\text { Observed dur- } \\
\text { ing the ARM } \\
\text { sub-case A } \\
\text { campaign }\end{array}$ & $168 \times 168 \times 20$ & Included & $\begin{array}{l}\Delta x, \quad \Delta y=200, \\
\text { and } \Delta z=100\end{array}$ \\
\hline & $\begin{array}{l}\text { High-aerosol- } \\
\text { no-ice run }\end{array}$ & $\begin{array}{l}\text { Same as in the } \\
\text { high-aerosol } \\
\text { run in DEEP }\end{array}$ & $\begin{array}{l}\text { Same as in the } \\
\text { high-aerosol } \\
\text { run in DEEP }\end{array}$ & $\begin{array}{l}\text { Same as in the } \\
\text { high-aerosol } \\
\text { run in DEEP }\end{array}$ & $\begin{array}{l}\text { Same as in the } \\
\text { high-aerosol } \\
\text { run in DEEP }\end{array}$ & $\begin{array}{l}\text { Same as in the } \\
\text { high-aerosol } \\
\text { run in DEEP }\end{array}$ & Not included & $\begin{array}{l}\text { Same as in the } \\
\text { high-aerosol } \\
\text { run in DEEP }\end{array}$ \\
\hline & $\begin{array}{l}\text { Low-aerosol } \\
\text { run }\end{array}$ & $\begin{array}{l}\text { Same as in the } \\
\text { high-aerosol } \\
\text { run in DEEP }\end{array}$ & $\begin{array}{l}\text { Same as in the } \\
\text { high-aerosol } \\
\text { run in DEEP }\end{array}$ & $\sim 400$ & $\begin{array}{l}\text { Same as in the } \\
\text { high-aerosol } \\
\text { run in DEEP }\end{array}$ & $\begin{array}{l}\text { Same as in the } \\
\text { high-aerosol } \\
\text { run in DEEP }\end{array}$ & Included & $\begin{array}{l}\text { Same as in the } \\
\text { high-aerosol } \\
\text { run in DEEP }\end{array}$ \\
\hline & $\begin{array}{l}\text { Low-aerosol- } \\
\text { no-ice run }\end{array}$ & $\begin{array}{l}\text { Same as in the } \\
\text { high-aerosol } \\
\text { run in DEEP }\end{array}$ & $\begin{array}{l}\text { Same as in the } \\
\text { high-aerosol } \\
\text { run in DEEP }\end{array}$ & $\begin{array}{l}\text { Same as in the } \\
\text { low-aerosol run } \\
\text { in DEEP }\end{array}$ & $\begin{array}{l}\text { Same as in the } \\
\text { high-aerosol } \\
\text { run in DEEP }\end{array}$ & $\begin{array}{l}\text { Same as in the } \\
\text { high-aerosol } \\
\text { run in DEEP }\end{array}$ & Not included & $\begin{array}{l}\text { Same as in the } \\
\text { high-aerosol } \\
\text { run in DEEP }\end{array}$ \\
\hline \multirow{4}{*}{ MID } & $\begin{array}{l}\text { High-aerosol } \\
\text { run }\end{array}$ & $\begin{array}{l}\text { Same as in } \\
\text { DEEP }\end{array}$ & $\begin{array}{l}\text { Same as in } \\
\text { DEEP }\end{array}$ & $\begin{array}{l}\text { Same as in the } \\
\text { high-aerosol } \\
\text { run in DEEP }\end{array}$ & $\begin{array}{l}\text { Same as in } \\
\text { DEEP but with } \\
\text { lower humidity } \\
\text { at the lowest } \\
\text { level }\end{array}$ & $\begin{array}{l}\text { Same as in } \\
\text { DEEP }\end{array}$ & Included & $\begin{array}{l}\text { Same as in } \\
\text { DEEP }\end{array}$ \\
\hline & $\begin{array}{l}\text { High-aerosol- } \\
\text { no-ice run }\end{array}$ & $\begin{array}{l}\text { Same as in } \\
\text { DEEP }\end{array}$ & $\begin{array}{l}\text { Same as in } \\
\text { DEEP }\end{array}$ & $\begin{array}{l}\text { Same as in the } \\
\text { high-aerosol } \\
\text { run in DEEP }\end{array}$ & $\begin{array}{l}\text { Same as in the } \\
\text { high-aerosol } \\
\text { run in M ID }\end{array}$ & $\begin{array}{l}\text { Same as in } \\
\text { DEEP }\end{array}$ & Not included & $\begin{array}{l}\text { Same as in } \\
\text { DEEP }\end{array}$ \\
\hline & $\begin{array}{l}\text { Low-aerosol } \\
\text { run }\end{array}$ & $\begin{array}{l}\text { Same as in } \\
\text { DEEP }\end{array}$ & $\begin{array}{l}\text { Same as in } \\
\text { DEEP }\end{array}$ & $\begin{array}{l}\text { Same as in the } \\
\text { low-aerosol run } \\
\text { in DEEP }\end{array}$ & $\begin{array}{l}\text { Same as in the } \\
\text { high-aerosol } \\
\text { run in MID }\end{array}$ & $\begin{array}{l}\text { Same as in } \\
\text { DEEP }\end{array}$ & Included & $\begin{array}{l}\text { Same as in } \\
\text { DEEP }\end{array}$ \\
\hline & $\begin{array}{l}\text { Low-aerosol- } \\
\text { no-ice run }\end{array}$ & $\begin{array}{l}\text { Same as in } \\
\text { DEEP }\end{array}$ & $\begin{array}{l}\text { Same as in } \\
\text { DEEP }\end{array}$ & $\begin{array}{l}\text { Same as in the } \\
\text { low-aerosol run } \\
\text { in DEEP }\end{array}$ & $\begin{array}{l}\text { Same as in the } \\
\text { high-aerosol } \\
\text { run in MID }\end{array}$ & $\begin{array}{l}\text { Same as in } \\
\text { DEEP }\end{array}$ & Not included & $\begin{array}{l}\text { Same as in } \\
\text { DEEP }\end{array}$ \\
\hline \multirow[t]{2}{*}{ SHALLOW } & $\begin{array}{l}\text { High-aerosol } \\
\text { run }\end{array}$ & $\begin{array}{l}\text { Same as in } \\
\text { DEEP }\end{array}$ & $\begin{array}{l}\text { Same as in } \\
\text { DEEP }\end{array}$ & $\begin{array}{l}\text { Same as in the } \\
\text { high-aerosol } \\
\text { run in DEEP }\end{array}$ & $\begin{array}{l}\text { Same as in } \\
\text { DEEP but with } \\
\text { strong positive } \\
\text { large-scale } \\
\text { temperature } \\
\text { forcing around } \\
\text { the freezing } \\
\text { level }\end{array}$ & $26 \times 26 \times 20$ & $\begin{array}{l}\text { Included but } \\
\text { not activated }\end{array}$ & $\begin{array}{l}\Delta x, \quad \Delta y=50, \\
\text { and } \Delta z=40 \\
\text { below } 2 \mathrm{~km}\end{array}$ \\
\hline & $\begin{array}{l}\text { Low-aerosol } \\
\text { run }\end{array}$ & $\begin{array}{l}\text { Same as in } \\
\text { DEEP }\end{array}$ & $\begin{array}{l}\text { Same as in } \\
\text { DEEP }\end{array}$ & $\begin{array}{l}\text { Same as in the } \\
\text { low-aerosol run } \\
\text { in DEEP }\end{array}$ & $\begin{array}{l}\text { Same as in the } \\
\text { high-aerosol } \\
\text { run in SHAL- } \\
\text { LOW }\end{array}$ & $\begin{array}{l}\text { Same as in the } \\
\text { high-aerosol } \\
\text { run in SHAL- } \\
\text { LOW }\end{array}$ & $\begin{array}{l}\text { Included but } \\
\text { not activated }\end{array}$ & $\begin{array}{l}\text { Same as in the } \\
\text { high-aerosol } \\
\text { run in SHAL- } \\
\text { LOW }\end{array}$ \\
\hline
\end{tabular}

Maximum CAPE is $\sim 2500 \mathrm{~J} \mathrm{~kg}^{-1}$ and maximum wind shear is $\sim 0.0075 \mathrm{~s}^{-1}$ in the high-aerosol run in DEEP. CAPE is the integral of parcel buoyancy from the surface to the domain top. Wind shear is the change of wind speed from one grid to the grid immediately above it, averaged over the lowest $6 \mathrm{~km}$, unless otherwise stated; Wilhelmson and Klemp (1978) showed that low-level shear below $6 \mathrm{~km}$ was more important to the development of modeled convection than upper-level shear. These CAPE and shear conditions support the development of deep cumulonimbus-type clouds (with anvil cirrus) (Bluestein, 1993).
To examine the aerosol effect, the high-aerosol run is repeated but with the aerosol number reduced by a factor of 10. This simulation is referred to as the low-aerosol run in DEEP. These reduced aerosols represent maritime aerosols. Also, the high- and low-aerosol runs are repeated with no ice physics in the same manner as in Lee et al. (2008a, b). These simulations are referred to as the high-aerosol-no-ice run and the low-aerosol-no-ice run. The comparison between the pair of high-aerosol runs and low-aerosol runs with and without ice physics is used to identify the effects of aerosols on freezing and any resulting invigoration of convection. The summary of simulations is shown in Table 1 . The other simulations in Table 1 are described in the following sections. 


\subsection{Idealized shallow convective clouds}

Additional simulations (a pair of the high-aerosol and the low-aerosol runs and a pair of the high-aerosol-no-ice and the low-aerosol-no-ice runs) for idealized convective clouds with lower cloud-top heights and thus shallower cloud depth than those in DEEP are carried out. This case of convective clouds is referred to as MID, henceforth. To better isolate the dependence of aerosol effects on the type of convective clouds (characterized by cloud-top height), differences in the environmental and aerosol conditions between DEEP and MID need to be minimized. For this, lower humidity forcing at the lowest level is imposed to generate the lower CAPE in MID as compared to DEEP, following Lee et al. (2008b), while the aerosol and other environmental conditions are identical to those in DEEP. The time- and area-averaged surface humidity forcing is $\sim 7.8 \mathrm{~g} \mathrm{~kg}^{-1} \mathrm{day}^{-1}$ in DEEP, while the averaged forcing is $\sim-1.4 \mathrm{~g} \mathrm{~kg}^{-1}$ day $^{-1}$ in MID. The initial areaaveraged surface water-vapor mixing ratio is $\sim 15.3 \mathrm{~g} \mathrm{~kg}^{-1}$ for both DEEP and MID. CAPE plays an important role in the determination of the types of convective clouds. This is because CAPE basically determines the intensity of updrafts (and thus of the convection). High (low) CAPE generally leads to high (low) updrafts, increasing (reducing) vertical transport of hydrometeors and, thus, cloud-top height. This relation between CAPE and cloud-top height was simulated in Lee et al. (2008b, 2009a).

\subsection{Idealized stratiform clouds}

Differences in the effect of aerosols on clouds between convective clouds and warm stratiform clouds were examined by repeating the high-aerosol and the low-aerosol runs for idealized conditions which lead to the formation of warm stratiform clouds. To generate the idealized stratiform clouds, identical meteorological and aerosol conditions to those in DEEP were applied except for the temperature forcing; a strong positive large-scale temperature forcing was applied around the freezing-level favoring the formation of an inversion layer and thus the formation of shallow warm stratiform clouds. This case of idealized stratiform clouds is referred to as SHALLOW, henceforth. As shown in Fig. 4a and b, depicting the vertical distribution of the area-averaged temperature forcing, negative temperature forcing is generally imposed in DEEP and MID above around $4 \mathrm{~km}$, whereas positive forcing is imposed with its peak around $4 \mathrm{~km}$ in SHALLOW.

\section{Results}

\subsection{Deep convective clouds}

Precipitation decreases in the low-aerosol run (Table 3) due to the reduced freezing and gustiness (as measured by the

\section{Temperature Forcing}

a

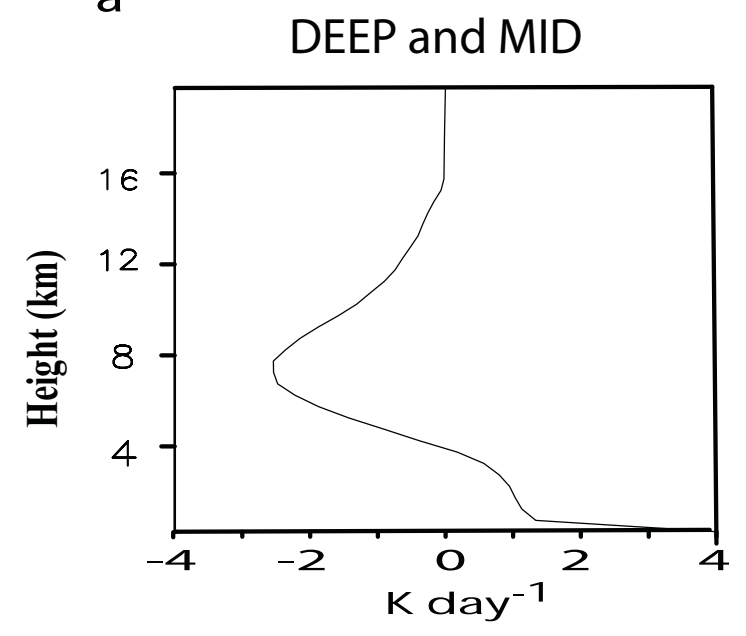

b

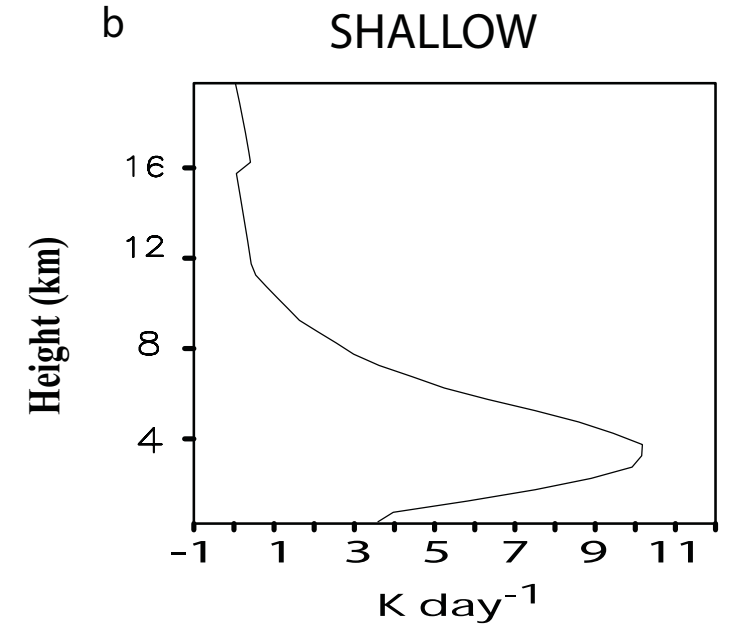

Fig. 4. Time- and domain-averaged vertical distribution of potential temperature large-scale forcing $\left(\mathrm{Kday}^{-1}\right)$ for (a) DEEP and MID and for (b) SHALLOW.

absolute value of low-level convergence $(|\nabla \bullet \vec{V}|)$ averaged over the lowest $1 \mathrm{~km}$; here, $\vec{V}$ is the horizontal wind vector) (see Table 2). The reduction of heat within the system by the evaporation of cloud liquid due to the increase in aerosol concentrations is $\sim 40$ times larger than that released by cloudliquid freezing as shown in Table 2 and Fig. 5. Figure 5 depicts the time- and domain-averaged vertical distribution of the rate of latent-heat changes due to evaporation and freezing for simulations in DEEP. This indicates that the effect of increased aerosols on evaporation plays a much more important role in the aerosol-induced latent-heat redistribution than that of freezing.

The high-aerosol-no-ice run still shows larger precipitation and the increase in precipitation in this run is similar to that in the high-aerosol run (Table 2). This indicates that the 
Table 2. Terms of the latent heat absorption and release and terms characterizing the cloud type and gustiness.

\begin{tabular}{|c|c|c|c|c|c|c|c|c|}
\hline Case & Simulation & $\begin{array}{l}\text { Domain- } \\
\text { averaged } \\
\text { cumula- } \\
\text { tive heat } \\
\text { reduction } \\
\text { from } \\
\text { evaporation } \\
\text { of cloud } \\
\text { liquid at the } \\
\text { last time } \\
\text { step }\left(10^{8} \mathrm{~J}\right. \\
\left.\mathrm{m}^{-2}\right)\end{array}$ & $\begin{array}{l}\text { Domain- } \\
\text { averaged } \\
\text { cumulative } \\
\text { latent heat } \\
\text { release } \\
\text { from con- } \\
\text { densation } \\
\text { at the last } \\
\text { time step } \\
\left(10^{8} \mathrm{~J}\right. \\
\left.\mathrm{m}^{-2}\right)\end{array}$ & $\begin{array}{l}\text { Domain- } \\
\text { averaged } \\
\text { cumulative } \\
\text { latent heat } \\
\text { release } \\
\text { from freez- } \\
\text { ing at the } \\
\text { last time } \\
\text { step }\left(10^{8} \mathrm{~J}\right. \\
\left.\mathrm{m}^{-2}\right)\end{array}$ & $\begin{array}{l}\text { Domain- } \\
\text { averaged } \\
\text { cumula- } \\
\text { tive heat } \\
\text { reduction } \\
\text { from } \\
\text { melting } \\
\text { at the last } \\
\text { time step } \\
\left(10^{8} \mathrm{~J}\right. \\
\left.\mathrm{m}^{-2}\right)\end{array}$ & $\begin{array}{l}\text { Average } \\
\text { cloud-top } \\
\text { height at } \\
\text { the time of } \\
\text { maximum } \\
\text { area- } \\
\text { averaged } \\
\text { precip- } \\
\text { itation } \\
(\mathrm{km})\end{array}$ & $\begin{array}{l}\text { Cumulative } \\
\text { number of } \\
\text { convective } \\
\text { cores at the } \\
\text { last time } \\
\text { step }\end{array}$ & $\begin{array}{l}\text { Averaged } \\
\text { low-level } \\
\text { conver- } \\
\text { gence } \\
\text { over } \\
\text { the low- } \\
\text { est } 1 \mathrm{~km} \\
\left(10^{-4} \mathrm{~s}^{-1}\right)\end{array}$ \\
\hline \multirow{4}{*}{ DEEP } & $\begin{array}{l}\text { High-aerosol } \\
\text { run }\end{array}$ & 1.48 & 1.95 & 0.043 & 0.028 & 11.1 & 237615 & 2.6 \\
\hline & $\begin{array}{l}\text { High-aerosol- } \\
\text { no-ice run }\end{array}$ & 1.53 & 2.00 & - & - & 10.8 & 200312 & 2.3 \\
\hline & $\begin{array}{l}\text { Low-aerosol } \\
\text { run }\end{array}$ & 0.79 & 1.16 & 0.024 & 0.021 & 10.9 & 188021 & 1.5 \\
\hline & $\begin{array}{l}\text { Low-aerosol- } \\
\text { no-ice run }\end{array}$ & 0.83 & 1.20 & - & - & 10.5 & 160506 & 1.4 \\
\hline \multirow{4}{*}{ MID } & $\begin{array}{l}\text { High-aerosol } \\
\text { run }\end{array}$ & 0.35 & 0.53 & 0.028 & 0.011 & 5.8 & 75100 & 1.1 \\
\hline & $\begin{array}{l}\text { High-aerosol- } \\
\text { no-ice run }\end{array}$ & 0.36 & 0.56 & - & - & 5.6 & 64211 & 0.8 \\
\hline & $\begin{array}{l}\text { Low-aerosol } \\
\text { run }\end{array}$ & 0.19 & 0.35 & 0.007 & 0.005 & 5.0 & 61348 & 0.8 \\
\hline & $\begin{array}{l}\text { Low-aerosol- } \\
\text { no-ice run }\end{array}$ & 0.23 & 0.38 & - & - & 4.9 & 60125 & 0.7 \\
\hline \multirow{2}{*}{ SHALLOW } & $\begin{array}{l}\text { High-aerosol } \\
\text { run }\end{array}$ & 0.05 & 0.08 & - & - & 1.3 & - & 0.3 \\
\hline & $\begin{array}{l}\text { Low-aerosol } \\
\text { run }\end{array}$ & 0.03 & 0.05 & - & - & 1.1 & - & 0.2 \\
\hline
\end{tabular}

effect of aerosols on evaporation and thus on gustiness accounts for most of the variation in precipitation induced by aerosol changes and that the effect of aerosols on freezing does not play a role as important as that on evaporation in the precipitation variation.

The role of the effect of aerosols on evaporation and gustiness in the aerosol-induced changes in precipitation in the experiments with no ice physics is examined. This examination enables us to isolate the effect of aerosols on gustiness with the exclusion of the effect of aerosols on ice physics through freezing.

The role of evaporation in gustiness is investigated by obtaining differences in variables associated with the intensity of the convergence between the high-aerosol-no-ice run and the low-aerosol-no-ice run. Figure 6 shows the time series of the difference (high aerosol - low aerosol) in domainaveraged evaporation rate of cloud liquid and rain, condensation rate, and mass concentration of cloud liquid, updraft mass flux, the lowest- $1 \mathrm{~km}$ downdraft mass flux and $|\nabla \bullet \vec{V}|$.
Around 18:30 GMT, cloud liquid at high aerosol begins to be more abundant, leading to larger evaporation of cloud liquid. Delayed autoconversion in the high-aerosol-no-ice run due to higher cloud droplet number concentration (CDNC) results in more abundant cloud liquid at high aerosol. Condensation is smaller at high aerosol due to weaker updrafts prior to $\sim 19: 10$ GMT. Evaporation of rain around 18:30 GMT at high aerosol is lower than at low aerosol, because less rain is produced by autoconversion at high aerosol, providing less rain to unsaturated areas.

Condensation, updrafts and evaporation of rain which contribute to the development of near-surface convergence are less active at high aerosol prior to 18:50 GMT when the convergence becomes more intense at high aerosol. Condensation and updraft become more active after $\sim 19: 00$ GMT as a result of more intense convergence at high aerosol. More evaporation of cloud liquid induces stronger low-level downdrafts (averaged over the lowest $1 \mathrm{~km}$ ) at high aerosol than at low aerosol around 18:30 GMT. Figure 7a and $7 \mathrm{~b}$ at 18:35 GMT ( $5 \mathrm{~min}$ after the development of stronger 
Table 3. Time- and area-averaged precipitation, liquid-water path (LWP) and top-of-the-atmosphere (TOA) shortwave cloud forcing (SCF) and longwave cloud forcing (LCF).

\begin{tabular}{|c|c|c|c|c|c|}
\hline & & $\begin{array}{l}\text { Precipitation } \\
(\mathrm{mm})\end{array}$ & $\begin{array}{l}\text { LWP } \\
\left(\mathrm{g} \mathrm{m}^{-2}\right)\end{array}$ & $\begin{array}{l}\mathrm{SCF} \\
\left(\mathrm{W} \mathrm{m} \mathrm{m}^{-2}\right)\end{array}$ & $\begin{array}{l}\mathrm{LCF} \\
\left(\mathrm{W} \mathrm{m}^{-2}\right)\end{array}$ \\
\hline Case & $\begin{array}{l}\text { Observed } \\
\text { Simulation }\end{array}$ & 33.2 & 55.2 & - & - \\
\hline \multirow{4}{*}{ DEEP } & $\begin{array}{l}\text { High-aerosol } \\
\text { run }\end{array}$ & 34.2 & 52.8 & -36.8 & 16.5 \\
\hline & $\begin{array}{l}\text { High-aerosol- } \\
\text { no-ice run }\end{array}$ & 31.5 & 56.3 & -37.5 & 16.9 \\
\hline & $\begin{array}{l}\text { Low-aerosol } \\
\text { run }\end{array}$ & 29.9 & 18.2 & -13.2 & 9.9 \\
\hline & $\begin{array}{l}\text { Low-aerosol- } \\
\text { no-ice run }\end{array}$ & 28.1 & 20.2 & -13.9 & 11.3 \\
\hline \multirow{4}{*}{ MID } & $\begin{array}{l}\text { High-aerosol } \\
\text { run }\end{array}$ & 6.5 & 40.9 & -30.2 & 12.0 \\
\hline & $\begin{array}{l}\text { High-aerosol- } \\
\text { no-ice run }\end{array}$ & 4.2 & 41.2 & -31.5 & 12.3 \\
\hline & $\begin{array}{l}\text { Low-aerosol } \\
\text { run }\end{array}$ & 5.3 & 18.5 & -11.2 & 8.4 \\
\hline & $\begin{array}{l}\text { Low-aerosol- } \\
\text { no-ice run }\end{array}$ & 5.0 & 21.9 & -11.8 & 8.9 \\
\hline \multirow{2}{*}{ SHALLOW } & $\begin{array}{l}\text { High-aerosol } \\
\text { run }\end{array}$ & 0.08 & 20.2 & -32.2 & 2.5 \\
\hline & $\begin{array}{l}\text { Low-aerosol } \\
\text { run }\end{array}$ & 0.5 & 15.3 & -10.3 & 1.8 \\
\hline
\end{tabular}

downdrafts at high aerosol) show that downdrafts are vertically collocated with the surface divergence fields. This indicates that the downdrafts spread out on the surface and thereby generate these divergence fields after reaching the surface. The downdrafts spread out to collide with the ambient warm air and generate the convergence fields (i.e., the gust fronts). More and stronger downdrafts generate more and stronger convergence fields in the high-aerosol-no-ice run than in the low-aerosol-no-ice run at 18:50 GMT (Fig. 6). This time sequence, in which increased cloud liquid and evaporation at high aerosol lead the development of, first, increased downdraft mass fluxes and convergence, and, finally, increased updraft mass fluxes and condensation, establishes causality.

Figure 8 at 19:15 GMT, which is 25 (5) min after the development of more intense low-level convergence (updrafts) at high aerosol as seen in Fig. 6, shows that updrafts are vertically collocated with the surface convergence lines. This indicates that the ambient air which is pushed upward more around the more intense gust front becomes the source of stronger updrafts at high aerosol. The more and stronger convergence induces more and stronger updrafts at 19:10 GMT and thus more condensation at 19:15 GMT in the highaerosol-no-ice run than in the low-aerosol-no-ice run on 29
June (Fig. 6). Then, a positive feedback between updrafts and condensation is established which further increases condensation and updrafts, resulting in more cumulative precipitation in the high-aerosol-no-ice run (see Lee et al., 2008a, b and Khain et al., 2008 for the positive relation between the variation of condensation and that of precipitation). This demonstrates that the aerosol-induced changes in the heat reduction associated with the evaporation of cloud liquid, leading to the increases in gustiness and subsequent updrafts and the latent-heat distribution associated with condensation, is alone able to enhance the precipitation with increasing aerosols with no effect of aerosols on ice physics.

The cumulative number of grid points corresponding to the regions in convective cores is $\sim 25 \%$ larger at high aerosol than at low aerosol (Table 2). The core regions are identified following Lee et al. (2008a). This indicates that the effect of aerosols on gustiness leads to more subsequent convective regions (contributing to more condensation) by generating more as well as stronger low-level convergence lines.

It should be pointed out that there are substantial increases not only in cloud liquid (Table 3 ) but also in cloud ice in the high-aerosol run mainly due to the aerosol-induced increased intensity of convection; the time- and domain-averaged ice water path (IWP) is 24.6 and $7.1 \mathrm{~g} \mathrm{~m}^{-2}$ for the high-aerosol 


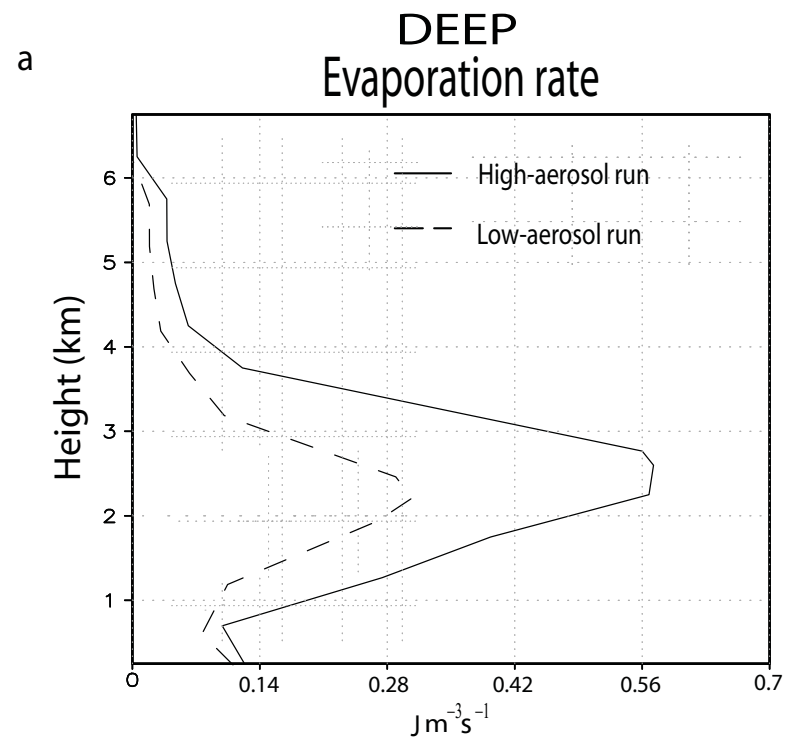

b

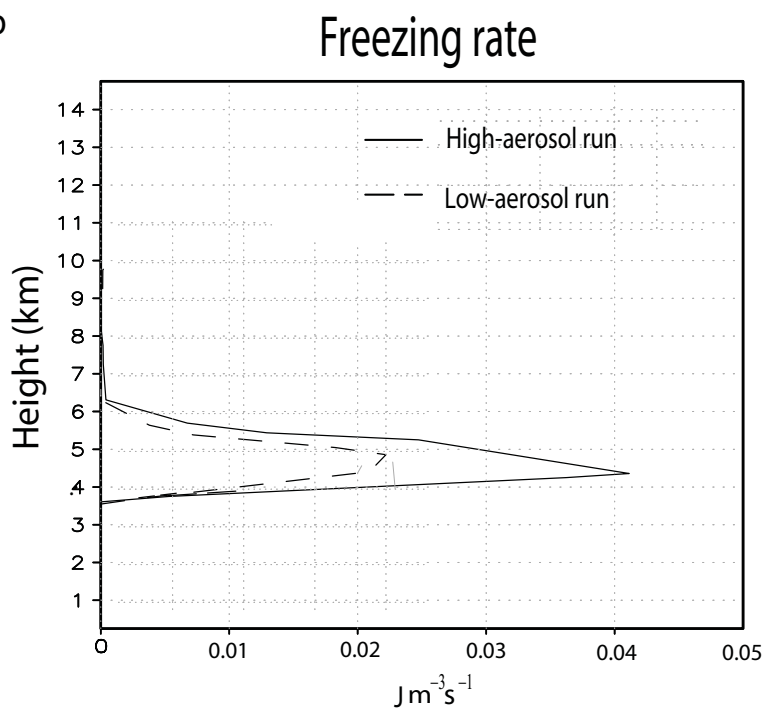

Fig. 5. Time- and domain-averaged vertical distribution of the rate of latent-heat changes due to (a) evaporation and (b) freezing for DEEP.

run and the low-aerosol run, respectively. This leads to a substantial offset in the aerosol-induced variation of negative shortwave cloud forcing (SCF) by that of positive longwave cloud forcing (LCF) at the top of the atmosphere. This is due to the substantial increase in absorption of longwave radiation from the surface at high aerosol. The SCF and LCF are calculated as clear-sky flux minus all-sky flux. The clear-sky fluxes are diagnosed by setting the mixing ratios of all the hydrometeors to zero with all the other variables unchanged at every time step for the high- and low-aerosol runs, respectively. As much as $28 \%$ of the increase in the negative SCF due to aerosol increases is offset by that of the LCF at the top of the atmosphere.

\section{Differences (High-Low) in Domain-Averaged Budget}

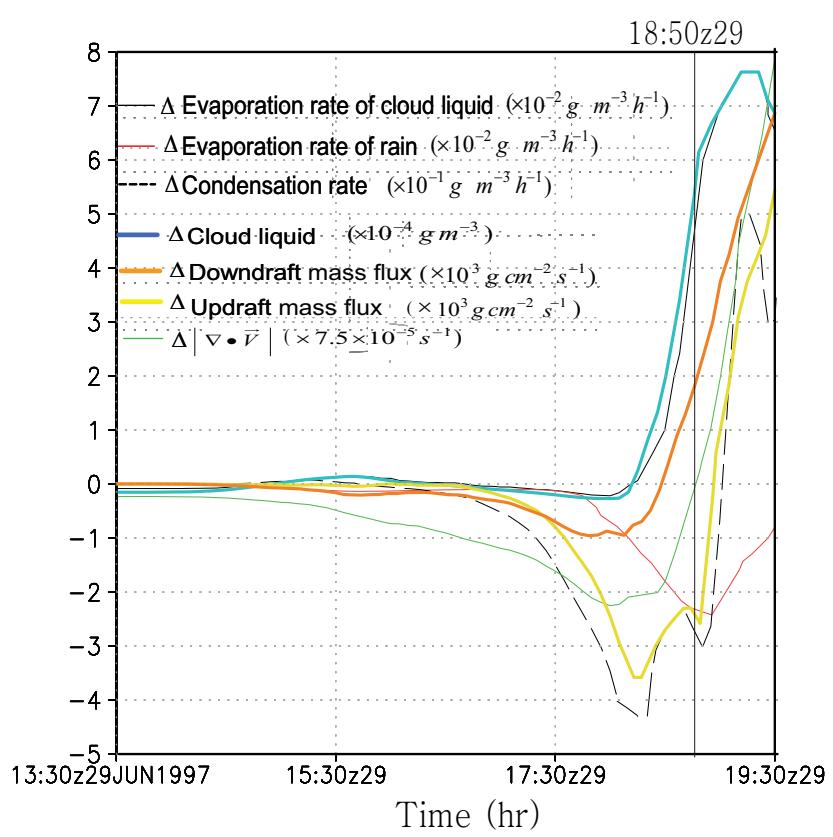

Fig. 6. Time series of difference (High - Low) in domain-averaged evaporation rate of cloud liquid and rain $\left(\times 10^{-2} \mathrm{~g} \mathrm{~m}^{-3} \mathrm{~h}^{-1}\right)$, condensation rate $\left(\times 10^{-1} \mathrm{~g} \mathrm{~m}^{-3} \mathrm{~h}^{-1}\right)$, cloud liquid mass concentration $\left(\times 10^{-4} \mathrm{~g} \mathrm{~m}^{-3}\right)$, updraft, downdraft mass fluxes $\left(\times 10^{3} \mathrm{~g} \mathrm{~cm}^{-2} \mathrm{~s}^{-1}\right)$, and $|\nabla \bullet \vec{V}|\left(\times 7.5 \times 10^{-5} \mathrm{~s}^{-1}\right)$ from the beginning of time integration to 19:30 GMT 29 June. Downdraft mass flux and $|\nabla \bullet \vec{V}|$ are averaged over the lowest $1 \mathrm{~km}$.

When cloud ice above the level of homogeneous freezing $(\sim 9 \mathrm{~km})$ is excluded only for the calculation of radiation with all the other variables unchanged in the same manner as in Lee et al. (2009a), the offset of the increased negative $\mathrm{SCF}$ by increased LCF with increasing aerosols is reduced to $17 \%$ at the top of the atmosphere, indicating that the effects of aerosol increases on the mass of anvil cirrus clouds play nearly as important a role as those on the mixed-phase and liquid clouds below the level of homogeneous freezing for the large offset in deep convective clouds simulated here.

\subsection{Idealized shallow convective clouds}

In MID, a maximum CAPE value of $\sim 800 \mathrm{~J} \mathrm{~kg}^{-1}$ is simulated, which supports the formation of low-level cumulus clouds (Bluestein, 1993) as simulated here (see Table 2 for the cloud-top height). Clouds here do not reach the level of homogeneous freezing and hence do not involve anvil cirrus clouds.

The differences in the intensity of gustiness and the number of convective cores between the high-aerosol run and the low-aerosol run are smaller in MID than in DEEP (Table 2). This is due to the weakened convective flow, leading to a 

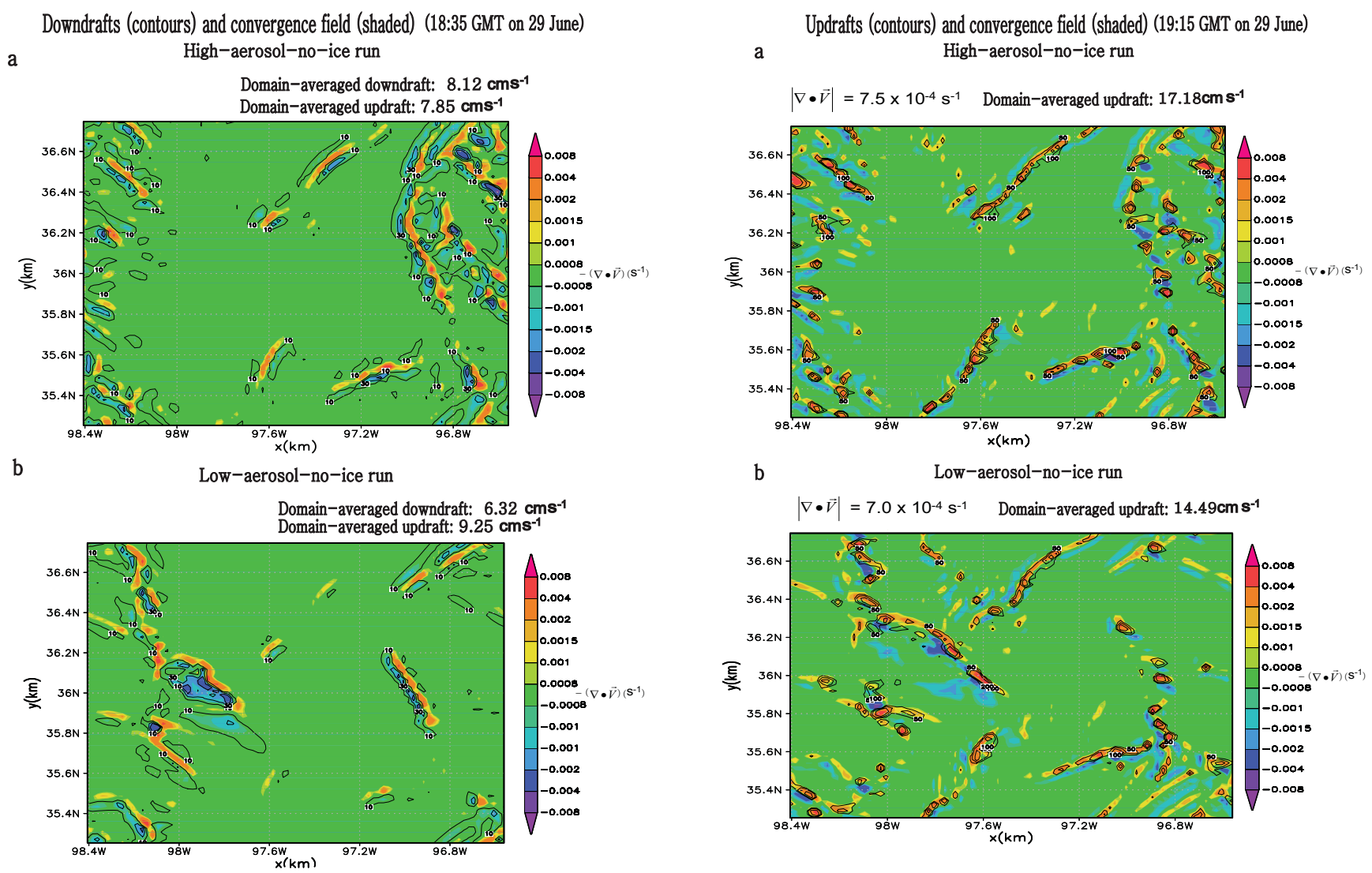

Fig. 7. (a) and (b) are the superimposition of the convergence field $\left(\mathrm{s}^{-1}\right)$ at the surface (represented by shading) and the vertically averaged downdrafts over the lowest $3 \mathrm{~km}$ (represented by contours for 10,30 , and $50\left(\mathrm{~cm} \mathrm{~s}^{-1}\right)$ ) for the high-aerosol-no-ice run and the low-aerosol-no-ice run at 18:35 GMT on 29 June. For reference, domain-averaged downdrafts and updrafts over the lowest $3 \mathrm{~km}$ and $4 \mathrm{~km}$ (where most of condensation occurs), respectively, at 18:35 GMT on 29 June are shown just above (a) and (b).

reduction in the transport of the cloud liquid to unsaturated areas, and a decreasing cloud-top height, leading to a reduction in the path to the surface which downdrafts follow. This decreases differences in evaporation and in the downdrafts between the high-aerosol run and the low-aerosol run, leading to a reduction in the differences in the low-level convergence. This leads to the reduction in the differences in the number of subsequent convective cores and in the intensity of the subsequent updrafts between the high-aerosol run and the low-aerosol run (Table 2 and Fig. 9). Due to reduced differences in the number of convective cores which contributes to reduced differences in updrafts with lowered CAPE, the increase in condensation in the high-aerosol run is not as large as in DEEP (Table 2). This leads to smaller increases in precipitation in the high-aerosol run than that in DEEP (Table 3).

In MID, ice physics is necessary to induce the precipitation-increase mechanism at high aerosol, since simulations with no ice physics showed more precipitation at low

Fig. 8. (a) and (b) are the superimposition of convergence field $\left(s^{-1}\right)$ at the surface (represented by shading) and the averaged updrafts over the lowest $4 \mathrm{~km}$ (represented by contours for 50, 100, and $\left.200\left(\mathrm{~cm} \mathrm{~s}^{-1}\right)\right)$ at 19:15 GMT on 29 June for the high-aerosolno-ice run and the low-aerosol-no-ice run in DEEP, respectively. For reference, domain-averaged $|\nabla \bullet \vec{V}|$ over the lowest $1 \mathrm{~km}$ and updrafts over the lowest $4 \mathrm{~km}$ are shown just above (a) and (b). Here, $\vec{V}$ is the horizontal wind vector.

aerosol (Table 3) than at high aerosol. Thus, aerosol effects on ice physics are more important in convective clouds with lower cloud-top heights and cloud depth (leading to weakened aerosol effects on gustiness).

The smaller differences in evaporative cooling, convergence, and updrafts between the high- and low-aerosol runs lead to smaller increases in cloud mass in MID than in DEEP at high aerosol. This, in turn, leads to an offset of only $19 \%$ of the increased negative SCF by increased LCF in MID, whereas DEEP had an offset of as much as $28 \%$ at the top of the atmosphere with increased aerosols. As the cloudtop height lowers, the offset by LCF (the so-called infrared warming effects) due to aerosols decreases.

\subsection{Idealized stratiform clouds}

The inversion layer caused by the imposed positive temperature forcing leads to a maximum CAPE of only $\sim 300 \mathrm{~J} \mathrm{~kg}^{-1}$. The horizontal domain length is set to $26 \mathrm{~km}$ in both the 


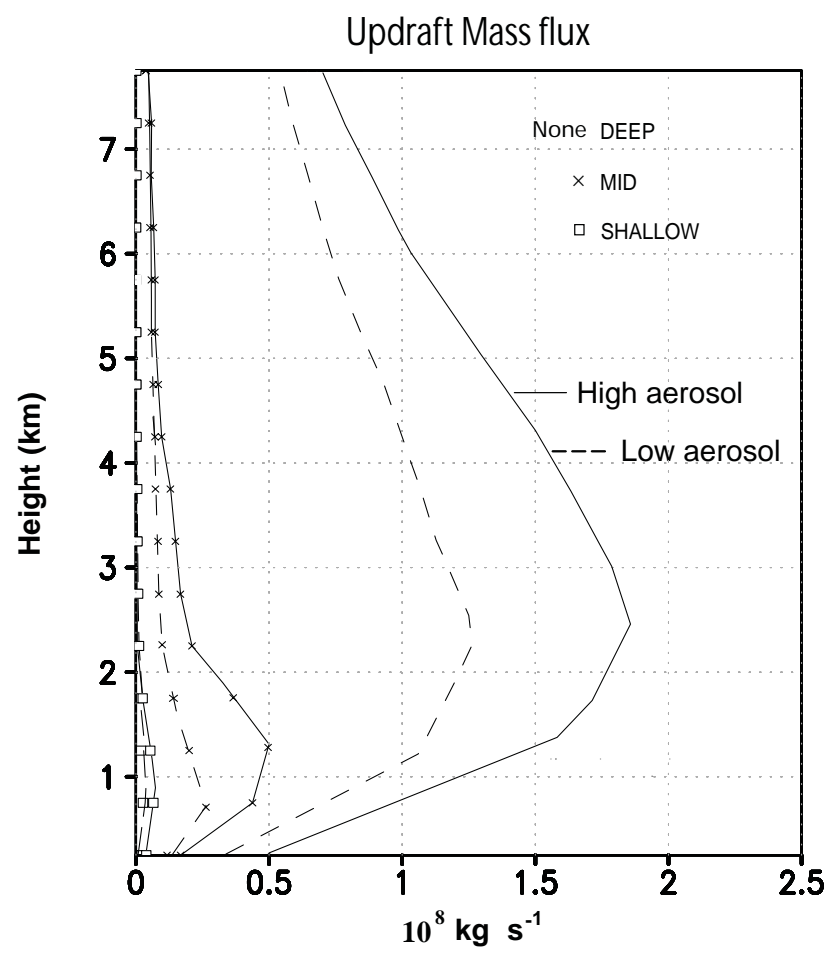

Fig. 9. Vertical distribution of time-averaged updraft mass flux for the high- and low-aerosol runs. The high- and low-aerosol runs for DEEP, MID, and SHALLOW include ice physics, though ice physics is not activated in SHALLOW.

east-west and north-south directions and the vertical domain length is $20 \mathrm{~km}$. The horizontal grid length is set to $50 \mathrm{~m}$ and the vertical spacing is uniformly $40 \mathrm{~m}$ below $2.0 \mathrm{~km}$ and then stretched to $240 \mathrm{~m}$ near the model top.

The detrainment of cloud liquid and associated evaporation in SHALLOW are smaller than those in the other cases, leading the smallest differences in evaporation between the high-aerosol and the low-aerosol runs (Table 2). Also, evaporatively driven differences in downdrafts at their level of initial descent are not magnified in SHALLOW as much as they are in DEEP and MID since they accelerate to the surface over the shortest distances; the cloud-top height is $\sim 1 \mathrm{~km}$ in SHALLOW (Table 2). These smaller differences in downdrafts lead to substantially reduced differences in the lowlevel convergence, and, thus, updrafts and condensation as compared to those in convective clouds (Table 2 and Fig. 9). Increases in condensation at high aerosol in SHALLOW do not balance the decreased autoconversion at high aerosol and result in less precipitation.

Increases in condensation at high aerosol in this case of stratiform clouds are mostly due to a microphysical reason identified in Lee et al. (2009c). Lee et al. (2009c) showed that just aerosol increases (per se) can increase condensation by providing increased total surface area of droplets where water vapor deposit. However, this study shows that this (mi- crophysical cause) alone cannot increase precipitation in a polluted case. A large cloud-depth for active interactions between microphysics and dynamics (i.e., downdarfts and gust front) is necessary for a sufficient increase in condensation which can lead to an increased precipitation with increased aerosols.

The substantially reduced increases in condensation in SHALLOW lead to a cloud-liquid increase of $\sim 50 \%$ in the high-aerosol run, an $\sim 6(\sim 4)$ times smaller percentage increase than that shown in DEEP (MID). This in turn leads to a much smaller offset of the increased negative SCF by increased LCF in SHALLOW than that in DEEP and MID. Only $\sim 3 \%$ of increased negative SCF is offset by increased LCF in SHALLOW.

\subsection{Size-distribution parameters}

Double-moment microphysics used here assumes a gamma size distribution for hydrometeors. Many observational studies indicate that cloud hydrometeors can be fit into the gamma size distribution reasonably well. Hence, the gamma size distribution used here is expected to represent the hydrometeor distribution adequately. Also, Seifert et al. (2006) indicated that the exact shape of size distribution of hydrometeors was not of importance to the reasonable simulation of precipitation. To test this indication, we repeated simulations for each of the cases by varying the shape parameter $(v)$ in Eq. (1) from 1 to 10 (see Walko et al. (1995) for the gamma distributions corresponding to the shape parameter from 1 to 10). For $v=1$, the gamma distribution reduces to the exponential or Marshall-Palmer distribution. From these simulations, we found that the qualitative nature of results here were robust to the shape parameter. This confirms the indication by Seifert et al., 2006 and demonstrates that results here are fairly robust to the assumption of size distribution.

\subsection{Effect of evaporative cooling on precipitation}

It is well-known that the convergence in a convective system is mostly controlled by evaporative cooling and downdrafts (see Houze, 1993 for details) as demonstrated by this study. However, to confirm the critical role evaporative cooling plays in the convergence and the precipitation response to aerosols in convective clouds, we carried out additional simulations by reducing the evaporative cooling of droplets in the high-aerosol case for DEEP and MID, respectively, following the methodology similar to that of Li et al. (2009b). We multiplied the droplet evaporation in the high-aerosol case by a reduction factor to make cumulative evaporation in the high-aerosol case to be identical to that in the lowaerosol case; the reduction factor is calculated based on the difference in the cumulative evaporation between the highaerosol and low-aerosol cases shown in Table 2. With a reduction only in the droplet evaporation in the high-aerosol case in DEEP, precipitation decreases in the high-aerosol 
case whether ice physics is included or not in these additional simulations. This demonstrates the critical role of the increase in droplet evaporation in the intensification of low-level convergence and precipitation enhancement with increasing aerosols. In MID, due to reduced droplet evaporation (leading to the reduced intensity of low-level convergence), precipitation decreases in the high-aerosol case in these additional simulations as compared to precipitation in the standard high-aerosol case whether ice physics is included or not. However, the sign of precipitation response to aerosols for each of cases with and without ice physics in MID does not change in these additional simulations as compared to that in the standard simulations. In these additional simulations with no ice for MID, less intensified low-level convergence in the high-aerosol case as compared to that in the standard high-aerosol case leads to more decreased precipitation in the high-aerosol case as compared to that in the standard high-aerosol case. With ice for MID in these additional simulations, though the intensity of low-level convergence decreases in the high-aerosol case (as compared to that in the standard high-aerosol case), the ice physics still enables more precipitation in the high-aerosol case.

Also, as shown in Fig. 5, depicting the vertical distribution of the rate of latent-heat changes due to evaporation and freezing, most of cloud-liquid evaporation and its difference between the high- and low-aerosol runs occur below the freezing level in DEEP; this also holds for the no-ice runs in DEEP and all of the runs for MID. Hence, cloud-liquid evaporation above the freezing level does have minor impacts on the results here.

\section{Summary and conclusion}

Rosenfeld et al. (2008) discussed the thermodynamic forcing (TF) of clouds. Rosenfeld et al. (2008) defined the TF as the aerosol-induced change in the atmospheric energy budget that is not radiative in nature. As seen here in the comparison between experiments with ice physics and with no ice physics, a large portion of the TF in deep convective clouds is accounted for by the effect of aerosols on evaporation and thus gustiness (which affects condensation) while the effect of aerosols on freezing (and thus melting) accounts for only $\sim 25 \%$ of the TF. This was shown by examining the difference in precipitation between experiments with no ice physics and those with ice physics. This indicates that the aerosol-induced changes in the latent-heat distribution and updrafts are mainly controlled by interactions between changes in evaporation and gustiness. The role of the interactions between changes in freezing and dynamics play a comparatively minor role in the aerosol-induced changes in the latent-heat distribution and updrafts in deep convection.

Each added millimeter of precipitation during $24 \mathrm{~h}$ can induce a TF of $29 \mathrm{~W} \mathrm{~m}^{-2}$ (Rosenfeld et al., 2008). The precipitation differences between the high-aerosol and the low- aerosol runs in DEEP are $4.3 \mathrm{~mm}$ and, hence, the TF is as much as $124.7 \mathrm{~W} \mathrm{~m}^{-2}$, which is quite large, considering that the change in the net radiative forcing (i.e., SCF+LCF) between the high-aerosol run and the low-aerosol run is $\sim 15 \mathrm{~W} \mathrm{~m}^{-2}$. The TF does not change the Earth's energy budget, but rather redistributes it internally, and hence can affect temperature gradients and atmospheric circulation (Rosenfeld et al., 2008). Thus, the large TF associated with changes in the evaporatively driven downdrafts in deep convective clouds (due to the transition of aerosols from maritime levels to continental levels) can modify the large-scale atmospheric circulation driven by deep convective clouds. For example, deep convective clouds in the ITCZ are the primary drivers for the Hadley circulation which plays a critical role in distributing heat from the tropics to the mid-latitudes. This study indicates that aerosol increases can increase the instability in the atmosphere by increasing the cooling associated with cloud-liquid evaporation. This increased instability is realized as an increased intensity of downdrafts and gustiness, leading to the subsequent development of stronger updrafts and thus more condensation and precipitation in the deep convective clouds simulated here. Hence, the possible modification of deep convective clouds in the ITCZ by aerosol-induced changes in the evaporation and thus the atmospheric instability can affect global circulation patterns. It is critical to understand and quantify the role of the aerosolinduced changes in the instability in deep convection in addition to their role in precipitation changes for a better prediction of climate changes.

It should be pointed out that the aerosol-induced increases in condensation increase droplets as a source of homogeneous freezing, a process accounting for most of the mass of anvil cirrus clouds. The increased cirrus mass plays an important role in the large offset of the increased negative SCF by increased LCF, which is $\sim 30 \%$ in deep convective clouds. This indicates that aerosol increases can increase the mass of cirrus clouds detrained from deep convection. Cirrus clouds regularly cover $20-25 \%$ of the globe and as much as $70 \%$ over the tropics and, thus, can act as one of major modulators of the global radiation budget (Liou, 1986, 2005). About half of the large-scale cirrus clouds have their origins in the upper layers detrained from deep, precipitation cloud systems (Houze, 1993). Hence, the aerosol-induced large offset by LCF (the so-called infrared warming effect) in deep convective clouds can be critical for the correct assessment of aerosol indirect effects. General circulation model (GCM) studies of aerosol effects on clouds have mainly focused on low-level stratiform clouds for the evaluation of changes in cloud radiative forcing by aerosol increases. Generally, they have not taken into account aerosol effects on deep convection or the links between these effects and detrained cirrus. This neglect will contribute to large uncertainties associated with the effects of ice clouds on radiation and aerosol indirect effects. 
This study also showed that the infrared warming effect varied with cloud types as characterized by the CAPEcontrolled cloud-top height. As the cloud-height lowers, the offset of the aerosol-induced changes in the negative SCF by the aerosol-induced changes in LCF decreases. This dependence of the relative magnitude of the variation in LCF to that in the negative SCF on cloud-top height indicates that changing environmental conditions due to climate change may impact the global offset of the variation in negative SCF by that in LCF. As an example, increases in temperature at the Earth's surface due to increases in greenhouse gases can increase the surface humidity, and, thereby, CAPE; the Clausius-Clapeyron equation indicates that the saturation water-vapor pressure increases exponentially with increasing temperature. As indicated in Weisman and Klemp (1982) and Bluestein (1993) and as simulated in DEEP and MID, CAPE plays an important role in the determination of cloud-top height; cloud-top height decreases with decreasing CAPE. Thus, it is expected that the offset of increased negative SCF by increased LCF will be larger with increasing greenhouse gases based on the comparisons of radiation among DEEP, MID, and SHALLOW where CAPE (and thus cloud-top height and the offset) increased. Hence, after industrialization, the environmental conditions changed in favor of an increasing offset of increased negative SCF by increased LCF due to aerosol increases. In other words, the warmer and more humid surface conditions increase the sensitivity of the offset to aerosol increases. The evaluation of this changing offset can be critical to the assessment of the response of climate to both greenhouse gases and aerosols, considering the strong sensitivity of the offset to the cloudtop height simulated here.

As shown in this study, the role of aerosol effects on gustiness is more critical than the role of aerosol effects on freezing for the development of increased precipitation with increases in aerosols in deep clouds but freezing becomes more important as clouds become shallower. Hence, the possible increases in CAPE with the increasing greenhouse gases act in favor of the role of the aerosol effects on gustiness by increasing the intensity of convective motions and the depth of clouds. Also, it should be pointed out that there are numerous numerical and observational studies (Khain et al., 2003, 2004, 2005, 2008; Lynn et al., 2005; Koren et al., 2005; Lin et al., 2006; Bell et al., 2008 and references therein) showing that increases in aerosols induce increases in the vigor and precipitation of convective clouds. According to the studies performed here, it seems that these changes cannot be ascribed solely to the responses of freezing and melting to aerosol changes as suggested by Rosenfeld et al. (2008), since many of the cases described in these studies involve deep convective clouds. Aerosol effects on liquid water evaporation and thus gustiness need to be considered for a better understanding of aerosol-cloud interactions in convective clouds.
The idealized modeling here shows that variations in CAPE can produce a range of convective responses to aerosols. However, variations of this nature do not preclude other interactions or thermodynamic factors as controls on the response of convection to variations in aerosols. For example, Khain et al. (2007) found that increasing aerosol can either decrease or increase surface precipitation, depending on humidity. Also, a given value of CAPE is not unique with respect to thermodynamic structure. For example, CAPE can be increased by increasing near-surface humidity or by increasing the middle-tropospheric lapse rate. The former approach has been used to generate the idealized CAPE variations in this paper. Varying the CAPE in this way may favor increased condensate production with a higher CAPE with increasing aerosols and the subsequent interactions described here. However, additional sensitivity tests where CAPE varied with changing tropospehric lapse rate showed that results here were fairly robust to whether changes in humidity or in lapse rate led to those in CAPE.

Li et al. (2009b) pointed out that a bulk microphysics can overestimate rain evaporation. This led to a development of a non-optimal structure of a squall line which had abnormal convective elements in the trailing stratiform clouds. $\mathrm{Li}$ et al. (2009b) used a single-moment microphysics coupled with a saturation adjustment. However, this study used a double-moment microphysics coupled with a supersaturation prediction. In addition, in this microphysics, the sedimentation of all hydrometeors, which is known to affect evaporation of precipitable hydrometeors significantly, is simulated by emulating a full-bin model with 36 bins (see Sect. 3 for details). This simulates the sedimentation with better confidence than previous treatments of sedimentation that use a mass-weighted fall speed, which is adopted in the singlemoment scheme in Li et al. (2009b). Using this sedimentation method in addition to the use of supersaturation prediction enables a better simulation of evaporation than a singlemoment microphysics. Hence, this study is able to simulate a well-defined trailing region of stratiform clouds with no convective cells.

Studies show coarse resolution or 2-D domain can contribute to unrealistically high updrafts, evaporation and precipitation (Phillips and Donner, 2007; Lee et al., 2009b; and Lee and Penner, 2010). In addition to the use of the single-moment microphysics coupled with the saturation adjustment, the use of rather coarse resolution and/or the use of 2-D domain may have contributed to the simulated larger updrafts, evaporation and precipitation with the single bulk scheme than with the bin scheme in Li et al. (2009a, b) and Khain et al. (2009) and Khain and Lynn (2009). The use of higher resolution (than Li et al. (2009a, b), Khain et al. (2009) and Khain and Lynn, 2009) and 3-D domain acts to minimize the possibility of occurrence of unrealistically high updrafts, evaporation and precipitation. Thus, this indicates that this possibility (associated with resolution and domain setup) is likely to be much lower in this study than that in 
Li et al. (2009a, b), Khain et al. (2009) and Khain and Lynn (2009).

This study used aerosol profiles produced by the GFDL AM2, since the 1997 ARM campaign does not provide aerosol data. However, as discussed in Lee et al. (2008a, b), aerosols only trigger feedbacks among downdrafts, gust front and condensation at the very beginning stage of simulations. These feedbacks are associated more with macrophysical processes (e.g., gust front, updrafts and downdrafts) than microphysical processes. Thus, microphysical details such as aerosol distributions do not have strong impact on these feedbacks and precipitation increase with increasing aerosols. After the feedbacks are triggered, those feedbacks themselves determine the response of precipitation to aerosol changes and the direct impact of aerosols on feedbacks and precipitation is nearly absent. This indicates that detailed aerosol data are not needed to simulate the precipitation-increase mechanism. Just the reasonable simulation of the aerosol-induced change in autoconversion (leading to changes in cloud-liquid amount as a source of evaporation) and evaporative cooling of droplets at the beginning stage of simulation is needed for the simulation of the feedbacks. Hence, although observed aerosol data are not used, the precipitation variation with aerosols is likely to be robust to what the original aerosol input is. To confirm this, we repeated the high-aerosol run in MID and DEEP with different aerosols. These different aerosols are also from AM2 and correspond to the minimum and the maximum aerosol number for the period between 28 and 30 June 1997. We compared these repeated high-aerosol runs with the maximum and minimum aerosols (with different aerosol size distributions) to the low-aerosol run in each of MID and DEEP. From this comparison, we found no changes in the qualitative nature of results; the minimum aerosol number is larger than the aerosol in the low-aerosol run and, thus, these repeated simulations with the minimum and maximum aerosol numbers both act as a high-aerosol run relative to the low-aerosol run and aerosol number varies between the minimum and the maximum by a factor of $\sim 6$.

Fan et al. (2009) showed a precipitation suppression at high aerosol in deep convection. They simulated an isolated deep convective cloud, while this study simulated a MCE. Hence, Fan et al. (2009) was not able to see the effect of aerosols on the subsequent development of secondary clouds over large domain through aerosol effects on downdrafts and low-level convergence which is simulated in this study. This study simulated invigorated convection (in terms of the averaged intensity of convection over the mesoscale domain) with a strong wind-shear condition based on the shear classification of Fan et al. (2009).

This study does not focus on the effect of environmental conditions such as wind shear and relative humidity on aerosol-cloud interactions in deep convection. However, for a MCE, when environmental humidity is high, an increase in evaporative cooling with increasing aerosols can decrease (efficiency of evaporation can be lowered when droplets are detrained into environment), which can lead to a decreased intensification of low-level convergence and a suppression of the mesocale cloud ensemble with increasing aerosols. But, the drying effect of entrained air into clouds will be lower with high humidity (Khain et al., 2008). However, when environmental humidity is low, the evaporation efficiency and thus the increase in evaporation with increasing aerosols (thus increase in the intensity of low-level convergence and condensation) will be larger, which can lead to the intensification of subsequent cloud and thus of the MCE. But, dry humidity increases the drying effect of entrained air into clouds and this can oppose the effect of evaporation on the low-level convergence and condensation in terms of the intensification of the MCE. Hence, there is a competition between entrainment and the effect of evaporation on the low-level convergence and subsequent condensation (with increasing aerosols) to determine the sign of the effect of aerosols on the intensity of cloud ensemble for a given humidity condition. The investigation of this competition between entrainment and interactions between evaporation and the low-level convergence and its variation with humidity merits future study. Also, with a weak wind-shear condition, we want to point out that the effect of evaporation on subsequent clouds through the intensification of low-level convergence can be weakened. Thus, a precipitation production through the aerosol-induced intensification of low-level convergence can be smaller with a weak wind-shear condition than simulated here. This can lead to the different effect of aerosols on precipitation than simulated here.

\section{Appendix A}

\section{Deposition nucleation at temperatures warmer than $-\mathbf{4 0}{ }^{\circ} \mathrm{C}$}

At temperatures between -30 and $-40{ }^{\circ} \mathrm{C}$ and between -5 and $-30^{\circ} \mathrm{C}$, DeMott et al. (2003) and Meyers et al.'s (1992) parameterizations, multiplied by a scaling factor, are used for deposition nucleation, respectively. For temperatures between -30 and $-40{ }^{\circ} \mathrm{C}$ :

$N_{\text {IN }}\left(\mathrm{m}^{-3}\right)=1000\left(\exp \left[12.96\left(S_{i}-1.1\right)\right]\right)^{0.3} \times \Psi$

Here, $N_{\text {IN }}$ is ice-crystal number concentration, $S_{i}$ the saturation ratio with respect to ice and $\Psi$ a scaling factor to take into account the dependence of IN activation on dust mass. $\Psi$ is $\frac{\mathrm{DU}_{2.5}}{\mathrm{DU}_{2.5}^{*}}$, where $\mathrm{DU}_{2.5}$ is mass concentration of dust particles with diameter less than $2.5 \mu \mathrm{m}$ and $\mathrm{DU}_{2.5}^{*}$ is a reference dust mass concentration. $\mathrm{DU}_{2.5}^{*}$ is set at $0.11 \mu \mathrm{g} \mathrm{m}^{-3}$ based on dust data from the Mount Werner project used to derive Eq. (A1) (DeMott et al., 2003). Hence, Eq. (A1) computes $N_{\text {IN }}$ based on variation of dust mass relative to dust mass observed at the Mount Werner project. It was observed that IN concentrations were almost linear with the concentrations 
of large aerosol particles (Berezinskiy et al., 1986; Georgii and Kleinjung, 1967), supporting the assumption that $N_{\mathrm{IN}}$ is proportional to $\mathrm{DU}_{2.5}$. For temperatures between -5 and $-30^{\circ} \mathrm{C}$, the same scaling factor as used in Eq. (A1) is applied to the parameterization of Meyers et al. (1992) as follows, since dust mass data are not available in Meyers et al. (1992):

$N_{\mathrm{IN}}\left(\mathrm{m}^{-3}\right)=63 \exp \left[12.96\left(S_{i}-1\right)-0.639\right] \times \Psi$

Acknowledgements. The authors wish to thank Venkatachalam Ramaswamy for valuable discussions. Seoung Soo Lee and Joyce E. Penner are grateful for the support of the DOE ARM Program under grant number DOE-DE-FG02-97-ER62370. Computer time was provided by the DOE NERSC facility.

Edited by: D. Knopf

\section{References}

Abdul-Razzak, H. and Ghan, S. J.: A parameterization of aerosol activation 2. Multiple aerosol types, J. Geophys. Res., 105, 6837-6844, 2000.

Abdul-Razzak, H. and Ghan, S. J.: A parameterization of aerosol activation - 3. Sectional representation, J. Geophys. Res., 107, 4026, doi:10.1029/2001JD000483, 2002.

Albrecht, B. A.: Aerosols, cloud microphysics, and fractional cloudiness, Science, 245, 1227-1230, 1989.

Bell, T. L., Rosenfeld, D., Kim, K.-M., Yoo, J.-M., Lee, M.-I., and Hahnenberger, M.: Midweek increase in U.S. summer rain and storm heights suggests air pollution invigorates rainstorms, J. Geophys. Res., 113, D02209, doi:10.1029/2007JD008623, 2008.

Bluestein, H. B.: Synoptic-Dynamic Meteorology in Midlatitudes: Volume II: Observations and Theory of Weather Systems (Synoptic-Dynamic Meteorology in Midlatitudes), Oxford University Press, 594 pp., 1993.

Chin, M., Ginoux, P., Kinne, S., et al.: Tropospheric Aerosol Optical Thickness from the GOCART Model and Comparisons with Satellite and Sun Photometer Measurements, J. Atmos. Sci., 59, 441-460, 2002.

Chou, M.-D. and Suarez, M. J.: A shortwave radiation parameterization for atmospheric studies. 15, NASA/TM-104606, 40 pp, 1999.

Chou, M.-D., Ridgway, W., and Yan, M.-H: Parameterizations for water vapor IR radiative transfer in both the middle and lower atmospheres, J. Atmos. Sci., 52, 1159-1167, 1999.

DeMott, P. J., Cziczo, D. J., Prenni, A. J., Murphy, D. M., Kreidenweis, S. M., Thomson, D. S., Borys, R., and Rogers, D. C.: Measurements of the concentration and composition of nuclei for cirrus formation, P. Natl. Acad. Sci. USA, 100(25), 1465514660, 2003.

Fan, J., Yuan, T., Comstock, J. M., et al.: Dominant role by vertical wind shear in regulating aerosol effects on deep convective clouds, J. Geophys. Res., 114, D22206, doi:10.1029/20009JD012352, 2009.

Feingold, G., Tzivion, S., and Levin, Z.: Evolution of raindrop spectra. Part I: Solution to the stochastic collection/breakup equation using the method of moments, J. Atmos. Sci., 45, 3387-3399, 1988.
Feingold, G., Cotton, W., Kreidenweis, S., and Davis, J.: The impact of giant cloud condensation nuclei on drizzle formation in stratocumulus: Implications for cloud radiative properties. J. Atmos. Sci., 56, 4100-4117, 1999.

Field, P. R., Möhler, O., Connolly, P., Krämer, M., Cotton, R., Heymsfield, A. J., Saathoff, H., and Schnaiter, M.: Some ice nucleation characteristics of Asian and Saharan desert dust, Atmos. Chem. Phys., 6, 2991-3006, doi:10.5194/acp-6-2991-2006, 2006.

Forster, P., Ramaswamy, V., Artaxo, P., et al.: Changes in atmospheric constituents and in radiative forcing, in: Climate change 2007: the physical science basis, Contribution of working group I to the Fourth Assessment Report of the Intergovernmental Panel on Climate Change, edited by: Solomon, S., Qin, D., Manning, M., et al., Cambridge Univ. Press, New York, 2007.

Houze, R. A.: Cloud dynamics, Academic Press, 573 pp., 1993.

Ghan, S., Laulainen, N., Easter, R., Wagener, R., Nemesure, S., Chapman, E., Zhang, Y., and Leung, R.: Evaluation of aerosol direct radiative forcing in mirage, J. Geophys. Res., 106, 52955316, 2001

Grabowski, W. W.: Indirect Impact of Atmospheric Aerosols in Idealized Simulations of Convective - Radiative Quasi Equilibrium, J. Climate, 18, 4664-4682, 2006.

Hall, W.: A detailed microphysical model within a two-dimensional dynamic framework: Model description and preliminary results, J. Atmos. Sci., 37, 2486-2507, 1980.

Hallett, J. and Mossop, S. C.: Production of secondary ice particles during the riming process, Nature, 249, 26-28, 1974.

Harrington, J. Y., Michael, P. M., Walko, R. L., and Cotton, R. C.: Parameterization of ice crystal conversion processes due to vapor deposition for mesoscale models using double-moment basis functions. Part I: Basic formulation and parcel model results, J. Atmos. Sci., 52, 4344-4366, 1995.

Heymsfield, A. J., Bansemer, A., Field, P. R., Durden, S. L., Stith, J. L., Dye, J. E., Hall, W., and Grainger, C.: Observations and parameterizations of particle size distribution in deep tropical cirrus and stratiform precipitating clouds: results from in situ observations in TRMM field campaigns, J. Atmos. Sci., 59, 3457-3491, 2005.

Houze, R. A.: Cloud dynamics, Academic Press, 573 pp., 1993.

Khain, A., Leung, L. R., Lynn, B., and Ghan, S.: Effects of aerosols on the dynamics and microphysics of squall lines simulated by spectral bin and bulk parameterization schemes, J. Geophy. Res., 114, D22203, doi:10.1029/2009JD011902, 2009.

Khain, A. and Lynn, B.: Simulation of a supercell storm in clean and dirty atmosphere using weather research and forecast model with spectral bin microphysics, J. Geophy. Res., 114, D19209, doi:10.1029/2009JD011827, 2009.

Khain, A., BenMoshe, N., and Pokrovsky, A.: Factors determining the impact of aerosols on surface precipitation from clouds: Attempt of classification, J. Atmos. Sci., 65, 1721-1748, 2008.

Khain, A. and Pokrovsky, A.: Simulation of Effects of Atmospheric Aerosols on Deep Turbulent Convective Clouds Using a Spectral Microphysics Mixed-Phase Cumulus Cloud Model. Part II: Sensitivity Study, J. Atmos.Sci., 24, 2983-3001, 2004.

Khain, A., Rosenfeld, D., and Pokrovsky, A.: Aerosol impact on the dynamics and microphysics of deep convective clouds, Q. J. Roy. Meteor. Soc., 131, 2639-2663, 2005.

Khain, A., Rosenfeld, D., and Pokrovsky, A.: Simulatoins of 
aerosol effects on convective clouds developed under continental and maritime conditions, Geophys. Res. Abstr., 5, 03180, 2003.

Klemp, J. B. and Wilhelmson, R.: The simulation of threedimensional convective storm dynamics, J. Atmos. Sci., 35, 1070-1096, 1978.

Koch, D. and Rind, D.: Beryllium 10/beryllium 7 as a tracer of stratospheric transport, J. Geophys. Res., 103, 3907-3918, 1998.

Koren, I., Y. J. Kaufman, Y. J., Rosenfeld, D., L. A. Remer, L. A., and Rudich Y.: Aerosol invigoration and restructuring of Atlantic convective clouds, Geophys. Res. Lett., 32, L14828, doi:10.1029/2005GL023187, 2005.

Koop, T., Luo, B. P., Tsias, A., and Peter, T.: Water activity as the determinant for homogeneous ice nucleation in aqueous solutions, Nature, 406, 611-614, 2000.

Kratz, D. P., Chou, M.-D., Yan, M.-H., and Ho, C.-H.: Minor trace gas radiative forcing calculations using the k-distribution method with one-parameter scaling, J. Geophy. Res., 103, 31647-31656, 1998.

Lee, S. S., Donner, L. J., Phillips, V. T. J., and Ming, Y.: Examination of aerosol effects on precipitation in deep convective clouds during the 1997 ARM summer experiment, Q. J. Roy. Meteor. Soc., 134, 1201-1220, 2008a.

Lee, S. S., Donner, L. J., Phillips, V. T. J., and Ming, Y.: The dependence of aerosol effects on clouds and precipitation on cloudsystem organization, shear and stability, J. Geophys. Res., 113, D16202, doi:10.1029/2007JD009224, 2008b.

Lee, S. S., Donner, L. J., and Phillips, V. T. J.: Sensitivity of aerosol and cloud effects on radiation to cloud types: comparison between deep convective clouds and warm stratiform clouds over one-day period, Atmos. Chem. Phys., 9, 2555-2575, doi:10.5194/acp-9-2555-2009, 2009a.

Lee, S. S., Penner, J. E., and Wang, M.: Comparison of a globalclimate model simulation to a cloud-system resolving model simulation for long-term thin stratocumulus clouds, Atmos. Chem. Phys., 9, 6497-6520, doi:10.5194/acp-9-6497-2009, 2009b.

Lee, S. S. and Penner, J. E.: Comparison of a global-climate model to a cloud-system resolving model for the long-term response of thin stratocumulus clouds to preindustrial and presentday aerosol conditions, Atmos. Chem. Phys., 10, 6371-6389, doi:10.5194/acp-10-6371-2010, 2010.

Lee, S. S, Penner, J. E., and Saleeby, S. M.: Aerosol effects on liquid-water path of thin stratocumulus clouds, J. Geophys. Res., 114, D07204, doi:10.1029/2008JD010513, 2009c.

Li, X., Tao, W.-K., Khain, A. P., Simpson, J., and Johnson, D. E.: Sensitivity of a Cloud-Resolving Model to Bulk and Explicit Bin Microphysical Schemes. Part I: Comparisons, J. Atmos. Sci., 66, 3-21, 2009a.

Li, X., Tao, W.-K., Khain, A. P., Simpson, J., and Johnson, D. E.: Sensitivity of a Cloud-Resolving Model to Bulk and Explicit Bin Microphysical Schemes. Part II: Cloud Microphysics and Storm Dynamics Interactions, J. Atmos. Sci., 66, 22-40, 2009b.

Lin, J. C., Matsui, T., Pielke Sr., R. A., and Kummerow, C.: Effects of biomass-burning-derived aerosols on precipitation and clouds in the Amazon Basin: a satellite-based empirical study, J. Geophys. Res., 111, D19204, doi:10.1029/2005JD006884, 2006.

Liou, K. N.: Cirrus clouds and climate in McGraw-Hill Yearbook of Science and Technology, 432 pp., 2005.

Liou, K. N.: Influence of cirrus clouds on weather and climate processes: A global perspective, Mon. Weather Rev., 114, 1167-
1199, 1986.

Lohmann, U. and Diehl, K.: Sensitivity studies of the importance of dust ice nuclei for the indirect aerosol effect on stratiform mixedphase clouds, J. Atmos. Sci., 63, 968-982, 2006.

Long, A.: Solutions to the droplet collection equation for polynomial kernels, J. Atmos. Sci., 31, 1040-1052, 1974.

Lynn, B. H., Khain, A. P., Dudhia, J., Rosenfeld, D., Pokrovsky, A., and Seifert, A.: Spectral (bin) microphysics coupled with a mesoscale model (MM5). Part I: Model description and first results, Mon. Weather Rev., 133, 44-58, 2005.

Meyers, M. P., DeMott, P. J., and Cotton, W. R.: New primary icenulceation parameterization in an explicit cloud model, J. Appl. Meteor., 45, 3-39, 1997.

Meyers, M. P., Walko, R. L., Harrington, J. Y., and Cotton, W. R.: New RAMS cloud microphysics parameterization: Part II. The two-moment scheme, Atmos. Res., 38, 29-62, 1995.

Möhler, O., Field, P. R., Connolly, P., Benz, S., Saathoff, H., Schnaiter, M., Wagner, R., Cotton, R., Krämer, M., Mangold, A., and Heymsfield, A. J.: Efficiency of the deposition mode ice nucleation on mineral dust particles, Atmos. Chem. Phys., 6, 3007-3021, doi:10.5194/acp-6-3007-2006, 2006.

Morrison, H., Thomson, G., and Tatarskii, V.: Impact of cloud microphysics on the development of trailing stratiform precipitation in a simulated squall line: Comparison of one- and two-moment schemes, Mon. Weather Rev., 137, 991-1007, 2009.

Penner, J. E., Andreae, M., Annegarn, et al.: Report to intergovernmental panel on climate change from the scientific assessment working group (WGI), in climate change 2001: The scientific basis, chap. 5, edited by: Houghton, J. T., Ding, Y., Griggs, D. J., et al., Cambridge Univ. Press, New York, 289-348, 2001.

Phillips, V. T. J., Sherwood, S. C., Andronache, C., Bansemer, A., Conant, W. C., DeMott, P. J., et al.: Anvil galciation in a deep cumulus updraft over Florida simulated with an explicit microphysics model. I: The impact of various nucleation processes, Q. J. Roy. Meteorol. Soc, 131, 2019-2046, 2005.

Phillips, V. T. J., Donner, L. J., and Garner, S.: Nucleation processes in deep convection simulated by a cloud-system-resolving model with double-moment bulk microphysics, J. Atmos. Sci., 64, 738761, 2007.

Phillips, V. T. J. and Donner, L. J.: Cloud microphysics, radiation and vertical velocities in two- and three-dimensional simulations of deep convection, Q. J. Roy. Meteor. Soc., 132, 3011-3033, 2006.

Ramanathan, V., Cess, R. D., Harrison, E. F., et al.: Cloud-Radiative Forcing and Climate: Results from the Earth Radiation Budget Experiment, Science, 243, 57-63, 1989.

Ramaswamy, V., Boucher, O., Haigh, J., et al.: Radiative forcing of climate change, in Climate Change 2001: The Scientific Basis, edited by: Houghton, J. T., Ding, Y., Griggs, D. J., et al., Cambridge Univ. Press, New York, 349-416, 2001.

Rosenfeld, D., Lohmann, U., Raga, G. B., O’Dowd, C. D., Kulmala, M., Fuzzi, S., Reissell, A., and Andreae, M. O.: Flood or drought: How do aerosols affect precipitation?, Science, 321, 1309-1313, 2008.

Saleeby, S. M. and Cotton, W. R.: A large-droplet mode and prognostic number concentration of cloud droplets in the Colorado state university regional atmospheric modeling system (RAMS). Part I: Module description and supercell test simulations, J. Appl. Meteor., 43, 182-195, 2004. 
Seifert, A., Khain, A., Pokrovsky, A., and Beheng, K. D.: A comparison of spectral and two-moment bulk mixed-phase cloud microphysics, Atmos. Res., 80, 46-66, 2006.

Simpson, J. and Tao, W.-K.: The Goddard Cumulus Ensemble model. Part II: Applications for studying cloud precipitating processes and for NASA TRMM, Terr. Atmos. Ocean. Sci., 4, 73116, 1993.

Soong, S.-T. and Ogura, Y.: Response of trade wind cumuli to largescale processes, J. Atmos. Sci., 37, 2035-2050, 1980.

Tao, W.-K., Li, X., Khain, A., Matsui, T., Lang, S., and Simpson, J.: The role of atmospheric aerosol concentration on deep convective precipitation: cloud-resolving model simulations, J. Geophys. Res., 112, D24S18, doi:10.1029/2007JD008728, 2007.

Tao, W.-K. and Simpson, J.: The Goddard Cumulus Ensemble model. Part I: Model description, Terr. Atmos. Ocean. Sci., 4, 19-54, 1993.
Tao, W.-K., Simpson, J., Baker, D., et al.: Microphysics, radiation and surface processes in the Goddard Cumulus Ensemble (GCE) model, Meteor. and Atmos. Phys., 82, 97-137, 2003.

Twomey, S.: The influence of pollution on the shortwave albedo of clouds, J. Atmos. Sci., 34, 1149-1152, 1977.

Walko, R. L., Cotton, W. R., Meyers, M. P., and Harrington, J. Y.: New RAMS cloud microphysics parameterization: Part I. The single-moment scheme, Atmos. Res., 38, 29-62, 1995.

Weisman, M. L. and Klemp, J. B.: The dependence of Numerically Simulated Convective Storms on Vertical Wind Shear and Buoyancy, Mon. Weather Rev., 110, 504-520, 1982

Wilhelmson, R. B. and Klemp, J. B.: A numerical study of storm splitting that leads to long lived storms, J. Atmos. Sci., 35, 19741986, 1978. 